\title{
Aerobic Exercise in the Management of Metabolic Dysfunction Associated Fatty Liver Disease
}

\author{
Mariana Verdelho Machado (iD) ${ }^{1,2}$ \\ 'Serviço de Gastrenterologia, Hospital de \\ Vila Franca de Xira, Vila Franca de Xira, \\ Portugal; ${ }^{2}$ Faculdade de Medicina, \\ Universidade de Lisboa, Lisboa, Portugal
}

Correspondence: Mariana Verdelho Machado

Faculdade de Medicina, Universidade de Lisboa, Avenida Professor Egas Moniz,

Lisboa, 1649-035, Portugal

$\mathrm{Tel}+351912620306$

Email mverdelhomachado@gmail.com

\begin{abstract}
Sedentarism is the pandemic of modern times. It is associated with several medical conditions including obesity, type 2 diabetes mellitus, cardiovascular diseases and also liver disease, particularly metabolic dysfunction associated fatty liver disease (MAFLD). In an era when MAFLD is the most prevalent chronic liver disease worldwide, whilst no pharmacological therapy has been approved for it, exercise has proved to be effective in improving liver steatosis. Interestingly, exercise decreases liver fat even in the absence of weight loss. The challenge for the clinician is to motivate the obese patient with MAFLD, and associated co-morbidities, who has crystallized a sedentary behavior, at times when every need is at the distance of a click on the Internet, and the entire world can be visited behind a screen. In this review, the aggregate evidence on the mechanisms and effects of exercise in the management of MAFLD is summarized, with simple recommendations for everyday clinical practice.
\end{abstract}

Keywords: metabolic dysfunction-associated fatty liver disease, physical activity, aerobic exercise

\section{Introduction}

Sedentarism and unhealthy dieting are the pandemic behaviors of the XXI century. ${ }^{1}$ Around $85 \%$ of the US population achieve less than what is preconized by the World Health Organization for daily physical activity for health. ${ }^{2}$ Up to one third of the world's population is physically inactive, which is strongly associated with obesity, type 2 diabetes mellitus, cardiovascular diseases and overall mortality. ${ }^{3-5}$ Physical inactivity is also associated with metabolic dysfunction-associated fatty liver disease (MAFLD), independently of body weight. ${ }^{6}$

MAFLD refers to the ectopic accumulation of fat in the hepatocytes, which can be explained by metabolic dysfunction associated with adiposopathy. Adiposopathy is the consequence of an energy overload in the adipose tissue, usually in overweight/obese patients. An overwhelmed adipose tissue can also arise in subjects with normal body mass index, in which the personal fat threshold, that is the amount of fat the individual adipose tissue can handle, is surpassed. ${ }^{7}$ The sick adipose tissue releases fat that accumulates ectopically in the liver, but also in the cardiovascular system, and promotes systemic inflammation, insulin resistance, and the metabolic syndrome. The fatty liver further enhances insulin resistance and derangements in lipid metabolism, ensuing in a loop of metabolic dysfunction. ${ }^{8}$ Recently, an international panel of experts proposed the following diagnostic criteria for MAFLD: ${ }^{9}$ presence of hepatic steatosis in patients with type 2 diabetes 
mellitus and/or who are overweight/obese. In lean nondiabetic patients, it requires evidence of hepatic steatosis and the presence of at least 2 of the following metabolic abnormalities: (1) Waist circumference (WC) $\geq 102$ and $88 \mathrm{~cm}$ in Caucasian men and women, respectively (or $\geq 90$ and $80 \mathrm{~cm}$ in Asian men and women, respectively); (2) Blood pressure $\geq 130 / 85 \mathrm{mmHg}$ or specific drug treatment; (3) Plasma triglycerides $\geq 150 \mathrm{mg} / \mathrm{dL}$ or specific drug treatment; (4) Plasma high-density lipoprotein (HDL)cholesterol $<40 \mathrm{mg} / \mathrm{dL}$ for men and $<50 \mathrm{mg} / \mathrm{dL}$ for women or specific drug treatment; (5) Prediabetes (ie, fasting glucose levels $100-125 \mathrm{mg} / \mathrm{dL}$, or 2-h post-load glucose levels 140-199 mg/dL or HbA1c 5.7-6.4\%); (6) Homeostasis model assessment (HOMA) of insulin resistance score $\geq 2.5$; (7) Plasma high-sensitivity C-reactive protein level $>2 \mathrm{mg} / \mathrm{L}$.

MAFLD,${ }^{9}$ is the liver pandemic of our times. It afflicts up to one fourth of the global population. ${ }^{10}$ It is also the most rapidly increasing etiology for end-stage liver disease, ${ }^{11}$ being the second leading cause of chronic liver disease in patients on waitlist for liver transplantation overall, but already the leading cause in women. ${ }^{12}$ Importantly, MAFLD is not only associated with an increased liver-related mortality but also associated with increased all-cause mortality. ${ }^{13}$ Indeed, even though a recent meta-analysis could not demonstrate an association between MAFLD and cardiovascular mortality, ${ }^{13}$ the presence of MAFLD increases over $60 \%$ the risk of having cardiovascular events, which cannot be solely explained by the association between MAFLD, obesity and the metabolic syndrome. ${ }^{14}$

Up to now, there is no approved treatment for MAFLD, and the management of these patients relies on the promotion of a healthy lifestyle, with diet and exercise, aiming for weight loss. ${ }^{15}$

The definition of sedentarism is not consensual and is often rendered as sitting time. Conversely, physical activity refers to any energy-requiring movement. Physical fitness is a set of attributes that reflect tolerance to physical activity and can be measured by specific tests. Exercise refers to planned physical activity that is structured and repetitive, with a specific intensity, frequency and duration. ${ }^{16}$ The intensity of exercise can be graded according to the metabolic equivalent tasks (METs) spent. One MET refers to the amount of oxygen consumed while sitting at rest, and corresponds to $3.5 \mathrm{~mL}$ of oxygen per $\mathrm{kg}$ of body weight per minute. One MET is equivalent to $1 \mathrm{kcal}$ per $\mathrm{kg}$ of body weight per hour. ${ }^{17}$ For example, walking at a speed of $4.8 \mathrm{kms}$ per hour is equivalent to 3 METs, while jogging at a speed of 6.4 to $8 \mathrm{kms}$ per hour is equivalent to 7 METs. Exercise is considered light when it spends 1.1-3.9 METs; moderate 4-6 METs and vigorous/ intense to more than 6 METs. Another way to represent it is according to the $\mathrm{VO}_{2} \max$, that is, the maximum capacity of oxygen utilization expressed as $\mathrm{L} / \mathrm{min} .{ }^{18}$ Exercise is considered moderate when requires $40-60 \%$ of $\mathrm{VO}_{2}$, and vigorous when it requires at least $60 \%$.

There are 3 different types of exercise: aerobic, resistance and flexibility. Aerobic or endurance exercise is rhythmic, can be maintained continuously and relies on large muscle groups. Resistance or strengthening exercise exerts muscle overload requiring anaerobic metabolism. Lastly, flexibility or stretching exercise aims to increase the joint range of motion and muscle extensibility. ${ }^{19}$

In this review, we will critically summarize the evidence of the effect of exercise on the management of MAFLD, with particular emphasis on aerobic exercise.

\section{What is the Role of Physical Activity in the Development and Progression of MAFLD?}

Epidemiological studies displayed an inverse correlation between physical activity and the prevalence of MAFLD, independently of the way physical activity was assessed: recalls, diaries, questionnaires or motion sensors/accelerometers, as shown in Table 1.

In a cross-section Korean study with 3718 participants, physical activity evaluated through structured questionnaires showed an inverse association with the risk of having MAFLD, which was independent of visceral adipose tissue. Indeed, being on the highest quartile of physical activity decreased by almost one third the risk of having MAFLD ${ }^{20}$ and to half the risk of developing de novo MAFLD. ${ }^{21}$ A large cohort of 42,661 participants from the Netherlands showed similar associations. ${ }^{22}$ Even lower levels of physical activity than the recommended (that is at least 150 minutes per week) conferred benefit over being entirely inactive. ${ }^{22}$ Furthermore, patients with insulin resistance/type 2 diabetes mellitus and elderly benefited the most. ${ }^{22}$

The association between physical activity, assessed by questionnaires, and MAFLD was corroborated by several studies in different populations: European, ${ }^{23}$ Israeli, ${ }^{24}$ Asian Indians, ${ }^{25}$ Chinese, ${ }^{26}$ and Korean. ${ }^{27}$ The aggregate studies suggested a dose-response association. ${ }^{26}$ Furthermore, the 
Table I Observational Studies Evaluating the Effect of Physical Activity on MAFLD

\begin{tabular}{|c|c|c|c|c|c|c|}
\hline Reference & Country & $\begin{array}{l}\text { Study } \\
\text { Design }\end{array}$ & $\mathbf{N}$ & $\begin{array}{c}\text { Evaluation of } \\
\text { Physical Activity }\end{array}$ & $\begin{array}{l}\text { Diagnosis of } \\
\text { MAFLD }\end{array}$ & Main Results \\
\hline $\begin{array}{l}\text { Perseghin G, } \\
2007^{23}\end{array}$ & Italy & $\begin{array}{l}\text { Cross- } \\
\text { sectional, } \\
\text { Cohort }\end{array}$ & 191 & Questionnaire & 'H-MRS & $\begin{array}{l}- \text { Inverse correlation between hepatic fat content } \\
\text { and PA. } \\
-\downarrow \text { prevalence of MAFLD according to quartile of } \\
\text { PA: } 25>\text { II }<25>2 \%\end{array}$ \\
\hline $\begin{array}{l}\text { Zelber-Sagi } \\
\text { S, } 2008^{24}\end{array}$ & Israel & $\begin{array}{l}\text { Cross- } \\
\text { sectional, } \\
\text { Cohort }\end{array}$ & 349 & $\begin{array}{l}\text { Self-reported PA in } \\
\text { the last year }\end{array}$ & Abdominal US & $\begin{array}{l}\text { - The MAFLD group engaged in less aerobic or } \\
\text { resistance PA }\end{array}$ \\
\hline $\begin{array}{l}\text { Kistler KD, } \\
20 \mathrm{II}^{42}\end{array}$ & USA & $\begin{array}{l}\text { Cross- } \\
\text { sectional, } \\
\text { Cohort }\end{array}$ & $\begin{array}{c}813 \\
\text { MAFLD } \\
\text { patients }\end{array}$ & $\begin{array}{l}\text { Self-reported PA } \\
\text { questionnaire from } \\
\text { the NHANES }\end{array}$ & Liver biopsy & $\begin{array}{l}\text { - Moderate-intensity PA did not associate with } \\
\text { steatohepatitis or fibrosis stage } \\
\text { - Vigorous PA } \downarrow \text { risk of steatohepatitis: OR } 0.65 \\
\text { [0.43-0.98] } \\
\text { - Doubling recommended time spent in vigorous } \\
\text { PA } \downarrow \text { risk of advanced fibrosis: OR } 0.53 \text { [0.29-0.97] }\end{array}$ \\
\hline $\begin{array}{l}\text { Gerber L, } \\
2012^{32}\end{array}$ & USA & $\begin{array}{l}\text { Cross- } \\
\text { sectional, } \\
\text { Cohort }\end{array}$ & 3056 & $\begin{array}{l}\text { Activity counts from } \\
\text { accelerometer } \\
\text { readings for } 7 \text { days }\end{array}$ & $\mathrm{FLI}>60$ & $\begin{array}{l}\text { - Patients with MAFLD spent less time participating } \\
\text { in activity at any level } \\
\text { - Average PA was } 28.7 \text { counts/minute/day lower in } \\
\text { MAFLD patients than controls }\end{array}$ \\
\hline $\begin{array}{l}\text { Bae JC, } \\
2012^{37}\end{array}$ & Korea & $\begin{array}{l}\text { Cross- } \\
\text { sectional, } \\
\text { Cohort }\end{array}$ & 72359 & $\begin{array}{l}\text { Self-reported } \\
\text { questionnaires }\end{array}$ & Abdominal US & $\begin{array}{l}\text { - Subjects who exercised }>3 x / \text { week, } \geq 30 \mathrm{~min} / \\
\text { session, for } 3 \text { consecutive months presented lower } \\
\text { risk of MAFLD: OR } 0.53-0.72\end{array}$ \\
\hline $\begin{array}{l}\text { Miyake T, } \\
2015^{38}\end{array}$ & Japan & $\begin{array}{l}\text { Cross- } \\
\text { sectional, } \\
\text { Cohort }\end{array}$ & 6370 & Questionnaire & Abdominal US & $\begin{array}{l}- \text { Periodical exercise } \downarrow \text { risk of having MAFLD: OR } \\
0.707[0.546-0.914]\end{array}$ \\
\hline $\begin{array}{l}\text { Kwak MS, } \\
2015^{20}\end{array}$ & Korea & $\begin{array}{l}\text { Cross- } \\
\text { sectional, } \\
\text { Cohort }\end{array}$ & 3718 & $\begin{array}{l}\text { PA questionnaire } \\
\text { from the NHANES }\end{array}$ & Abdominal US & $\begin{array}{l}\text { - PA was inversely associated with MAFLD: } \\
\text { - 4th vs Ist quartile: OR } 0.68 \text { [0.54-0.85] } \\
\text { - 3rd vs Ist quartile: OR } 0.74 \text { [0.59-0.93] }\end{array}$ \\
\hline Ryu S, $2015^{6}$ & Korea & $\begin{array}{l}\text { Cross- } \\
\text { sectional, } \\
\text { Cohort }\end{array}$ & 139056 & $\begin{array}{l}\text { International PA } \\
\text { Questionnaire Short } \\
\text { Form (Korean } \\
\text { version) }\end{array}$ & Abdominal US & $\begin{array}{l}- \text { Prevalence of MAFLD } \downarrow \text { in physically active vs } \\
\text { inactive: } \\
- \text { Minimally active group: OR } 0.94 \text { [0.02-0.95] } \\
\text { - HEPA group: OR } 0.8 \text { [0.78-0.82] } \\
\text { - Prevalence of MAFLD } \uparrow \text { with increasing sitting } \\
\text { time: } \\
-5-9 \text { hours/day: OR } 1.04[1.02-1.07] \\
-\geq 10 \text { hours/day: OR } 1.09[1.06-1.1 \mathrm{I}]\end{array}$ \\
\hline $\begin{array}{l}\text { Hallsworth } \\
\mathrm{K}, 2015^{33}\end{array}$ & UK & $\begin{array}{l}\text { Cross- } \\
\text { sectional, } \\
\text { Case- } \\
\text { control }\end{array}$ & $\begin{array}{c}37 \\
\text { MAFLD, } \\
37 \\
\text { controls }\end{array}$ & $\begin{array}{l}\text { Sedentary behaviour, } \\
\text { PA and E expenditure } \\
\text { were assessed by } \\
\text { a multisensor array } \\
\text { over } 7 \text { days }\end{array}$ & 'H-MRS & $\begin{array}{l}\text { - MAFLD patients compared to controls: } \\
\text { - Spent an hour extra per day being sedentary } \\
\text { - Walked } 18 \% \text { fewer steps } \\
\text { - } \downarrow \text { active E expenditure by } 40 \% \\
\text { - } \downarrow \text { total E expenditure by } 8 \%\end{array}$ \\
\hline $\begin{array}{l}\text { Tsunoda K, } \\
2016^{43}\end{array}$ & Japan & $\begin{array}{l}\text { Prospective } \\
\text { cohort, FU } \\
4.2 \text { years }\end{array}$ & 1149 & Questionnaire & $\begin{array}{l}\text { MAFLD: by US; } \\
\text { steatohepatitis } \\
\text { by } \uparrow \text { ALT or } \\
\text { AST }\end{array}$ & $\begin{array}{l}\text { - Vigorous PA prevented progression to } \\
\text { steatohepatitis: OR } 0.55[0.32-0.94] \\
\text { - Moderate or low intensity PA presented no } \\
\text { association with progression to steatohepatitis }\end{array}$ \\
\hline
\end{tabular}

(Continued) 
Table I (Continued).

\begin{tabular}{|c|c|c|c|c|c|c|}
\hline Reference & Country & $\begin{array}{l}\text { Study } \\
\text { Design }\end{array}$ & $\mathbf{N}$ & $\begin{array}{l}\text { Evaluation of } \\
\text { Physical Activity }\end{array}$ & $\begin{array}{l}\text { Diagnosis of } \\
\text { MAFLD }\end{array}$ & Main Results \\
\hline $\begin{array}{l}\text { Sung KC, } \\
2016^{40}\end{array}$ & Korea & $\begin{array}{l}\text { Prospective } \\
\text { cohort, FU } \\
4.95 \text { years }\end{array}$ & 169347 & $\begin{array}{l}\text { International PA } \\
\text { Questionnaire Short } \\
\text { Form (Korean } \\
\text { version) }\end{array}$ & Abdominal US & $\begin{aligned} & \bullet \geq 5 \times / \text { week exercise vs no exercise: } \\
& \bullet \downarrow \text { risk of incident steatosis: OR } 0.86 \text { [0.80-0.92] } \\
& \bullet \uparrow \text { likelihood of steatosis resolution: OR } 1.40 \\
& {[1.25-1.55] }\end{aligned}$ \\
\hline $\begin{array}{l}\text { Wei H, } \\
2016^{28}\end{array}$ & China & $\begin{array}{l}\text { Cross- } \\
\text { sectional, } \\
\text { Cohort }\end{array}$ & $\begin{array}{l}2054 \\
\text { male }\end{array}$ & $\begin{array}{l}\text { Self-reported } \\
\text { questionnaire }\end{array}$ & $\mathrm{FLI} \geq 60$ & $\begin{array}{l}\text { - Dose-dependent } \uparrow \text { prevalence of MAFLD across } \\
\text { the tertiles of sitting time. } \\
\text { - Sitting time }>7 . \text { hours/day associated with } \uparrow \\
\text { prevalence of MAFLD (OR } 1.09 \text { [1.04-I.67]) }\end{array}$ \\
\hline $\begin{array}{l}\text { Keating SE, } \\
2016^{34}\end{array}$ & Australia & $\begin{array}{l}\text { Cross- } \\
\text { sectional, } \\
\text { Cohort }\end{array}$ & 82 & $\begin{array}{l}\text { Activity counts from } \\
\text { accelerometer } \\
\text { readings for } 4 \text { days }\end{array}$ & 'H-MRS & $\begin{array}{l}\text { - No associations between PA and sedentary } \\
\text { behavior and the prevalence of MAFLD }\end{array}$ \\
\hline $\begin{array}{l}\text { Kwak MS, } \\
2017^{21}\end{array}$ & Korea & $\begin{array}{l}\text { Prospective } \\
\text { cohort, FU } \\
4.2 \text { years }\end{array}$ & 1373 & $\begin{array}{l}\text { PA questionnaire } \\
\text { from the NHANES }\end{array}$ & $\begin{array}{l}\text { Incident } \\
\text { MAFLD by US }\end{array}$ & $\begin{array}{l}\text { - Total and leisure PA was inversely associated with } \\
\text { incident MAFLD } \\
\text { - } \downarrow \text { PA at FU associated with } \uparrow \text { incident MAFLD: 4th } \\
\text { quartile vs Ist quartile of } \downarrow \text { PA OR I.45 [I.04-2.02] }\end{array}$ \\
\hline $\begin{array}{l}\text { Byambasukh } \\
\text { O, } 2019^{22}\end{array}$ & Netherlands & $\begin{array}{l}\text { Cross- } \\
\text { sectional, } \\
\text { Cohort }\end{array}$ & 42661 & $\begin{array}{l}\text { Self reported } \\
\text { questionnaire to } \\
\text { evaluate HEPA }\end{array}$ & $\mathrm{FLI} \geq 60$ & $\begin{array}{l}\text { - Higher moderate/vigorous PA was dose- } \\
\text { dependently associated with } \downarrow \text { risk of MAFLD: OR } \\
\text { for PA quintiles: } 0.78[0.71-0.86]>0.64[0.58-0.70] \\
>0.53[0.48-0.59]>0.51[0.46-0.56] \\
\text { - Even PA lower than recommendations was better } \\
\text { than inactivity } \\
\text { - Occupational PA offers no clear health benefits }\end{array}$ \\
\hline Li YF, $2019^{26}$ & China & $\begin{array}{l}\text { Cross- } \\
\text { sectional, } \\
\text { Case- } \\
\text { control }\end{array}$ & $\begin{array}{l}543 \\
\text { MAFLD, } \\
543 \\
\text { controls }\end{array}$ & $\begin{array}{l}\text { International PA } \\
\text { Questionnaire Short } \\
\text { Form (Chinese } \\
\text { version) }\end{array}$ & Abdominal US & $\begin{array}{l}- \text { Both moderate (OR } 0.62[0.41-0.92]) \text { or vigorous } \\
\text { (OR } 0.60[0.40-0.9 I]) \text { intensity PA associated with } \\
\downarrow \text { risk of MAFLD in men, independently of sedentary } \\
\text { time or E expenditure }\end{array}$ \\
\hline $\begin{array}{l}\text { Jang DK, } \\
2019^{27}\end{array}$ & Korea & $\begin{array}{l}\text { Cross- } \\
\text { sectional, } \\
\text { Case- } \\
\text { control }\end{array}$ & 32391 & $\begin{array}{l}\text { Self reported } \\
\text { questionnaire to } \\
\text { evaluate HEPA }\end{array}$ & $\begin{array}{c}\text { Hepatic } \\
\text { steatosis index }\end{array}$ & $\begin{array}{l}\text { - PA negatively associated with MAFLD (most vs } \\
\text { least active: OR } 0.7[0.6-0.8]) \text { and lean MAFLD (OR } \\
0.5[0.4-0.7])\end{array}$ \\
\hline $\begin{array}{l}\text { Gerage AM, } \\
2019^{41}\end{array}$ & Brazil & $\begin{array}{l}\text { Prospective } \\
\text { cohort, FU } \\
2.5 \text { years }\end{array}$ & 5860 & $\begin{array}{l}\text { International PA } \\
\text { Questionnaire }\end{array}$ & Abdominal US & $\begin{array}{l}\text { - Lower likelihood of improving steatosis in } \\
\text { subjects who remained inactive (OR } 0.64 \text { ) or } \\
\text { became inactive (OR } 0.66) \\
\text { - Lower risk of acquiring MAFLD in subjects who } \\
\text { remained active (OR } 0.75 \text { ) or became active (OR } 0.75 \text { ) }\end{array}$ \\
\hline $\begin{array}{l}\text { Bhatt SP, } \\
2019^{25}\end{array}$ & India & $\begin{array}{l}\text { Cross- } \\
\text { sectional, } \\
\text { Case- } \\
\text { control }\end{array}$ & 342 & Questionnaire & Abdominal US & $\begin{array}{l}\text { - Mean PA was lower in cases than controls ( } 33.3 \\
\pm 3.6 \text { vs } 36.2 \pm 0.5 \mathrm{MET} / \mathrm{min}) \\
\text { - Total E expenditure was lower in cases than } \\
\text { controls }(2707.6 \pm 505.6 \text { vs } 2904.3 \pm 690.3 \mathrm{kcal})\end{array}$ \\
\hline $\begin{array}{l}\text { Croci I, } \\
2019^{29}\end{array}$ & Australia & $\begin{array}{l}\text { Cross- } \\
\text { sectional, } \\
\text { Cohort }\end{array}$ & |578| & $\begin{array}{l}\text { Self-reported } \\
\text { questionnaire }\end{array}$ & $\mathrm{FLI} \geq 60$ & $\begin{array}{l}\text { - For each additional I hour/day of sedentary } \\
\text { behavior, the risk of having MAFLD } \uparrow 4 \%[3-6] \\
\text { - High cardiorespiratory fitness attenuated the } \\
\text { negative role of sedentary behavior up to } 7 \text { hours/ } \\
\text { day on MAFLD. }\end{array}$ \\
\hline
\end{tabular}

(Continued) 
Table I (Continued).

\begin{tabular}{|l|c|c|c|c|c|l|}
\hline Reference & Country & $\begin{array}{c}\text { Study } \\
\text { Design }\end{array}$ & N & $\begin{array}{c}\text { Evaluation of } \\
\text { Physical Activity }\end{array}$ & $\begin{array}{c}\text { Diagnosis of } \\
\text { MAFLD }\end{array}$ & Main Results \\
\hline $\begin{array}{l}\text { J00 JH, } \\
2020^{30}\end{array}$ & Korea & $\begin{array}{c}\text { Cross- } \\
\text { sectional, } \\
\text { Cohort }\end{array}$ & 13518 & $\begin{array}{c}\text { International PA } \\
\text { Questionnaire } \\
\text { (Korean version) }\end{array}$ & $\begin{array}{c}\text { Hepatic } \\
\text { steatosis index }\end{array}$ & $\begin{array}{l}\text { - The offs of having MAFLD increased across } \\
\text { quartiles of sitting hours: } 1.07[0.88-1.31]<1.16 \\
{[1.06-1.41]<1.34[1.11-1.61]}\end{array}$ \\
\hline $\begin{array}{l}\text { Kim D, } \\
2021^{52}\end{array}$ & USA & $\begin{array}{c}\text { Prospective } \\
\text { cohort, FU } \\
10.6 \text { years }\end{array}$ & $\begin{array}{c}5207 \\
\text { MAFLD } \\
\text { patients }\end{array}$ & PA questionnaire & Abdominal US & $\begin{array}{l}\bullet \uparrow \text { duration of PA inversely associated with all- } \\
\text { cause mortality (higher vs lower quartile: OR 0.46 } \\
{[0.28-0.75] \text { ) and cardiovascular mortality (OR 0.28 }} \\
{[0.008-0.98] \text { ) in patients with MAFLD }}\end{array}$ \\
\hline
\end{tabular}

Abbreviations: E, energy; FLI, Fatty Liver Index; HEPA, health-enhancing physically active; NHANES, National Health and Nutrition Examination Survey; PA, physical activity; US, ultrasound.

protective effect of physical activity was equally strong in patients with lean MAFLD. ${ }^{27}$

A cross-sectional study on 139,056 Korean, who underwent a comprehensive annual or biennial health examination, showed that spending more than 5 hours sitting per day increased the risk of having ultrasonography-diagnosed MAFLD. ${ }^{6}$ Other studies in Asian and Australian populations confirmed a dose-response association between sitting time and the prevalence of MAFLD. ${ }^{28-30}$ Indeed, spending more than 7 hours sitting per day increased by $10 \%$ the risk of MAFLD, independently of body mass index (BMI), insulin resistance and dyslipidemia. ${ }^{28}$ The detrimental effect of spending more than 10 hours sitting per day persisted even in those who were otherwise physically active. ${ }^{6}$ These results point out to the difference between inactivity and absence of exercise. Indeed, a small study on 19 overweight or obese adults showed that decreasing sitting time through 2 minutes bouts of light to moderate intensity walking was effective in decreasing insulin resistance. ${ }^{31}$

Other studies used a more objective way to quantify physical activity, such as accelerometers. Indeed, a study with 3056 participants from the National Health and Nutrition Examination Survey (NHANES) evaluated the physical activity during 7 consecutive days through accelerometer readings. When the accelerometer recorded less than 100 counts per minute per day, the patient was considered sedentary. MAFLD was diagnosed when fatty liver index (FLI) was higher than 60 and in the absence of other chronic liver diseases. In this study, patients with MAFLD spent less time participating in any activity, and presented an average of around less than 30 counts/min/day as compared to controls. ${ }^{32}$ Similarly, a small study from Newcastle, UK, evaluated 7-days physical activity and energy expenditure using a multisensory array on 37 patients with MAFLD and 1000 healthy controls. MAFLD patients spent an extra hour being sedentary, walked up to one-fifth fewer steps and expended $40 \%$ less energy being active. ${ }^{33}$ A small study from Australia failed to corroborate this association, ${ }^{34}$ when hepatic steatosis was measured by magnetic resonance spectrometry (MRS).

Importantly, not all physical activities seem to equally promote health. Indeed, it is leisure or recreational, and not occupational, physical activity that seems to induce the most benefits in health. Recreational physical activity usually induces the contraction of large muscle groups while increasing whole-body metabolism and cardiac output. During recreational physical activity one can rest when fatigued. Occupational physical activity more frequently involves heavy lifting, prolonged standing, and highly repetitive movements. ${ }^{35}$ Epidemiologic studies suggest an inverse, dose-response association between the risk of hypertension and recreational, but not occupational, physical activity. ${ }^{35}$ Furthermore, recreational physical activity is associated negatively, whereas occupational positively, with BMI, central obesity and insulin resistance. $^{36}$ Similarly, large-population studies have shown that recreational, but not occupational, physical activity seems to be protective against having MAFLD. ${ }^{22}$

Regarding the practice of exercise, a large population Korean study also showed that subjects that practiced exercise at least 3 times per week, for at least 30 minutes each time for more than 3 months, decreased up to half the risk of having MAFLD. ${ }^{37} \mathrm{~A}$ cross-sectional study from a subsample of 375 participants in the Israeli National Health And Nutrition Survey showed that engaging in any kind of sports decreased one-third the risk of having 
MAFLD, per each standard deviation increase in the physical activity score. These associations were stronger for resistance exercise as compared to aerobic exercise, which was explained by probable misclassification of selfreported physical activity. ${ }^{24}$ Similar results were shown on a large Japanese cohort. ${ }^{38}$ Furthermore, engagement in regular exercise also seems to be associated with protection from incident MAFLD, improvement and remission of MAFLD. ${ }^{39-41}$ Those effects presented a doseresponse pattern and occurred for any amount of exercise. $^{40}$

Engaging in physical activity not only seems to confer protection from having MAFLD, but it is also associated with less severe disease, in a dose-dependent manner. Two large-population studies from the US and Japan showed that engaging in vigorous, but not moderate, physical activity decreased the chances of progression to steatohepatitis and liver fibrosis. ${ }^{42,43}$ The authors hypothesized that vigorous physical activity consumes large amounts of ATP, which activates AMP kinase, eliciting increased ATP production through fatty acids oxidation and glucose transport. ${ }^{44}$ Furthermore, vigorous physical activity can lead to depletion of hepatic glycogen, triggering fat consumption. ${ }^{43}$

Another way to evaluate the role of physical activity on the development of MAFLD is through physical fitness, translating the ability of the subject to engage physical activity. Physically fit subjects, assessed using maximal treadmill exercise test or cycle ergometer data, seem less susceptible to having MAFLD, steatohepatitis, and severe liver fibrosis, independently of BMI. ${ }^{45-50}$

A recent study followed 125,264 participants from the Nurses' Health Study and the Health Professionals Follow up Study, for up to 25 years. It showed that higher physical activity also predicted a lower risk of liver-related mortality, across all the range of BMI. Physical activity could even abrogate the excessive liver-related mortality observed with obesity. Indeed, walking at least 3 hours per week could have prevented $25 \%$ of liver-related deaths. ${ }^{51}$ Furthermore, engaging in physical activity seems to have a profound impact on the survival of patients with MAFLD. A study that evaluated 5207 participants from the NHANES followed them for 10 years, assessing physical activity by accelerometer readings. The duration spent on physical activity was inversely associated with all-cause mortality. Subjects with the highest quartile of physical activity presented a more than half decreased risk of all-cause mortality compared to the lowest quartile of physical activity. The effect was even stronger for cardiovascular mortality. ${ }^{52}$ A different Australian cohort that also followed MAFLD patients over a 10 -year period and showed that low cardiorespiratory fitness was associated with a $50 \%$ increase in allcause mortality. ${ }^{29}$

\section{Physiopathology of Exercise and MAFLD}

MAFLD occurs when there is an imbalance between fat uptake and triglycerides production in the liver, and hepatic fat oxidation. Most of the fat uptake into the liver derives from the adipose tissue, particularly visceral adipose tissue. Insulin resistance promotes the release of fat from the adipose tissue that can reach the liver, and also, increases hepatic lipogenesis. In the liver, lipotoxicity can induce cell stress, through different mechanisms, such as oxidative stress, ER stress, impaired autophagy and cell death. ${ }^{8}$ Metabolic systemic inflammation and gut dysbiota also seem to play a role in the development and progression of MAFLD. ${ }^{53}$ Physical activity and exercise can protect against MAFLD through several mechanisms, acting on different players, such as the adipose tissue, the muscle, directly on the liver and on the gut microbiota ${ }^{54}$ (Figure 1).

Exercise can decrease visceral adiposity, particularly aerobic exercise. ${ }^{55}$ The decrease in visceral adipose tissue decreases the influx of free fatty acids into the liver. ${ }^{56} \mathrm{It}$ also decreases the metabolic-associated systemic inflammation while improving the adipokine profile (inducing an increase in adiponectin and a decrease in leptin). ${ }^{57,58}$ Exercise not only decreases the quantity of the adipose tissue but also changes the structure and function of the adipocyte. The importance of the qualitative changes in the adipose tissue induced by exercise can be illustrated by an interesting experiment in which recipient sedentary mice were transplanted with adipose tissue from trained donor mice (voluntary wheel running for 11 days). The recipient mice experienced a dramatic improvement in glucose tolerance. $^{59}$

Exercise decreases adiposity by decreasing the size of the adipocytes and its lipid content. ${ }^{60}$ This is of extreme relevance since the enlargement of adipocytes induces cellular stress (for example, oxidative and ER stress), ${ }^{61,62}$ leading to a distinct adipokine profile, to insulin resistance $^{63}$ (which increases its lipolytic capacity by spilling out of free fatty acids into the circulation), ${ }^{64}$ and to 


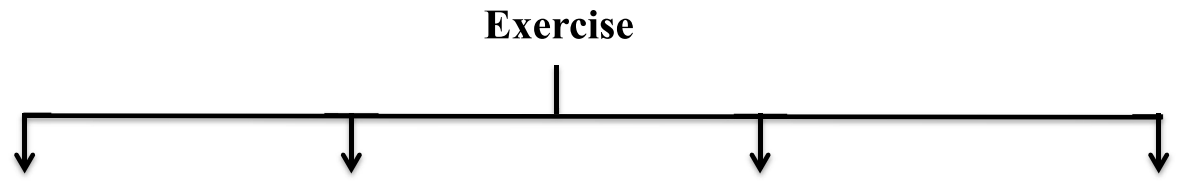

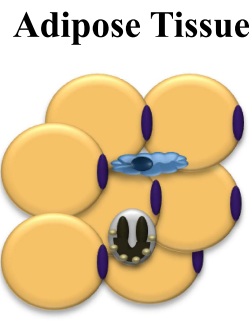

- $\quad \downarrow$ VAT mass and adipocyte size

- $\downarrow$ VAT inflammation

- beijing of WAT with $\uparrow$ energy expenditure

- $\downarrow$ release of NEFA's

- $\uparrow$ insulin sensitivity

- $\uparrow$ adiponectin

- $\downarrow$ leptin

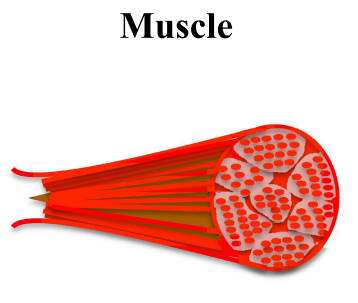

- $\uparrow$ energy expenditure

- $\uparrow$ mitochondrial mass and function

- $\uparrow$ insulin sensitivity

- $\uparrow$ glucose uptake and glycogen storage

- $\uparrow$ fatty acids uptake, oxidation and storage

- $\uparrow$ irisin

- $\downarrow$ myostatin
Liver

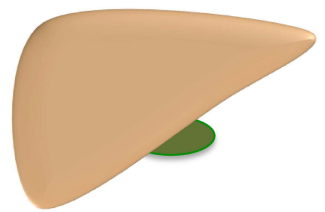

- $\quad \downarrow$ de novo lipogenesis

- $\uparrow$ fatty acids oxidation

- $\quad \downarrow$ oxidative stress

- $\quad \downarrow$ ER stress

- $\quad \downarrow$ inflammation

- $\uparrow$ autophagy

- $\downarrow$ apoptosis

- $\quad \downarrow$ fibrogenesis

- $\quad \downarrow$ carcinogenesis
Gut Microbiota

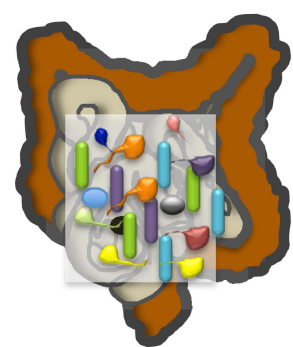

- $\uparrow$ microbial biodiversity

- modulates gut microbiota to a more anti-steatogenic and insulin-sensitizer effect

- preserves intestinal barrier

Figure I The anti-steatogenic mechanisms of exercise.

Abbreviations: VAT, visceral adipose tissue; WAT, white adipose tissue; NEFA's, non-esterified fatty acids; ER, endoplasmic reticulum.

cell death ${ }^{65}$ promoting adipose tissue inflammation. ${ }^{66}$ Furthermore, exercise induces beijing of the white adipose tissue, conferring a brown-like phenotype, with increased mitochondrial activity, ${ }^{59}$ increased uncoupling proteins leading to increased thermogenesis and increased energy expenditure. $^{67,68}$

Exercise also protects against MAFLD through its effects on the muscle. Regular exercise increases the muscle capacity for oxygen consumption and oxidative function, by increasing capillary density and increasing muscle mitochondrial content and function, ${ }^{69}$ for example through upregulation of proteins involved in mitochondrial biogenesis, such as peroxisome proliferator-activated receptor gamma (PPAR- $\gamma$ ) co-activator 1-alpha (PGC1 $\alpha) .{ }^{18}$

The muscle is the main tissue for glucose uptake and storage. ${ }^{70}$ Exercise and muscle contraction promote muscle glucose uptake by the translocation of the glucose receptor GLUT-4 into the cellular membrane, independently of insulin action, and by increasing muscle insulin sensitivity. ${ }^{71,72}$ Also, exercise increases the muscle glucose storage as glycogen. ${ }^{73,74}$ On the other hand, during exercise, the redistribution of blood flow from the splanchnic circulation to the working muscles, redirects circulating free fatty acids from the liver into the muscle. ${ }^{75}$ Indeed, regular exercise increases the uptake and oxidation of fatty acids by the muscle, as well as the ability to store fatty acids such as intramyocellular triglycerides. ${ }^{76}$ The relative contribution of glucose as fuel, compared to fat, increases with work rate, but declines with exercise duration. ${ }^{77}$ Furthermore, in the post-exercise period, glucose oxidation decreases at the expense of fat oxidation, in order to replenish glycogen storage. $^{78}$

Lastly, exercise modulates myokines production. $^{7}$ Exercise induces the release of irisin that promotes beijing of white adipose tissue, increasing energy expenditure. ${ }^{68}$ Irisin also has direct anti-steatogenic effects on the liver, through activation of PPAR- $\gamma$ and upregulation of fibroblast growth factor (FGF)-21. ${ }^{79}$ On the other hand, exercise downregulates myostatin, ${ }^{80}$ a myokine that promotes adipose tissue expansion through direct effects on the adipose tissue and through downregulation of irisin. ${ }^{81,82}$ Myostatin can also promote hepatic fibrogenesis through direct action on hepatic stellate cells. ${ }^{83}$ Moreover, exercise increases transiently the synthesis of interleukin(IL)- $6,{ }^{84}$ 
which induces subsequent increase in IL-10, IL-1 receptor antagonist and cortisol, with a net anti-inflammatory effect. ${ }^{85}$

Exercise has independent anti-steatogenic effects on the liver. Studies on animal models showed that exercise decreases de novo lipogenesis by downregulating the lipogenic transcription factor sterol regulatory-element binding protein-1c (SREBP-1c) ${ }^{86,87}$ and decreasing the levels and activity of key enzymes in lipid synthesis such as acetyl CoA carboxylase (ACC) and fatty acids synthase (FAS) ${ }^{88}$ Simultaneously, exercise increases hepatic mitochondrial fatty acids oxidation, by upregulating the lipolytic transcription factor PPAR- $\gamma^{89}$ and increasing the activity of key enzymes in beta-oxidation such as betahydroxyacyl-CoA-dehydrogenase $\quad(\beta-\mathrm{HAD}), \quad$ citrate synthase and cytochrome c oxidase. ${ }^{90-92}$

Exercise has an anti-oxidant effect on the liver, which translates into a decrease in lipid peroxidation, an increase in reduced glutathione content, and an increase in the activity of anti-oxidant enzymes, such as catalase, superoxide dismutase and glutathione peroxidase. ${ }^{93-98}$ It also has an anti-inflammatory effect, through a decrease in systemic inflammation mediated by the adipose tissue ${ }^{99}$ and the muscle, ${ }^{85}$ and through direct effects on the liver. Exercise decreases the hepatic tumor necrosis factor-alpha $(\mathrm{TNF}-\alpha)$ and hepatic resident macrophages infiltration. ${ }^{100,101}$ Furthermore, it inhibits the expression of toll-like receptors (TLR) on monocytes and macrophages, ${ }^{102}$ and increases the pool of $\mathrm{T}$ regulatory cells. ${ }^{103}$ Physical activity/exercise modulates other important cellular pathways: it promotes hepatoprotective autophagy, ${ }^{104}$ and it improves mitochondrial function, protecting the mitochondria from structural damage. ${ }^{105-107}$ Moreover, exercise attenuates mitochondrial-dependent hepatocyte apoptosis. ${ }^{108-110}$ All those actions are hepatoprotective, with the potential to decrease the progression from isolated steatosis to steatohepatitis and hepatic fibrosis. Animal studies also suggested exercise to decrease the risk of hepatocellular carcinoma in steatotic livers. ${ }^{111-113}$

Finally, exercise can modulate the gut microbiota towards a less steatogenic and insulin sensitizer phenotype. Indeed, in humans, exercise is associated with an increase in microbial richness/diversity, ${ }^{114,115}$ an increase in the relative proportion of Bacteroidetes and Euryarchaeota, whereas a decrease in Actinobacteria, at the phylum level. ${ }^{116,117}$ Obesity and MAFLD are known to be associated with a decrease in the Bacteroidetes/ Firmicutes ratio, which is associated with higher efficiency in harvesting energy from the diet. ${ }^{53}$ Furthermore, exercise helps preserve the intestinal barrier, and improves bile acids homeostasis. ${ }^{118}$

\section{Aerobic Exercise and MAFLD}

Several studies, mostly randomized controlled studies, and 7 meta-analyses evaluated the effect of structured interventions on aerobic exercise in MAFLD ${ }^{119-125}$ as shown in Table 2. Studies used different exercise regimens, with different intensities, and with durations ranging ${ }^{121}$ from 1 week ${ }^{109}$ to 1 year. ${ }^{126}$ Most of them showed improvements in hepatic steatosis. ${ }^{54,127,128} \mathrm{~A}$ small percentage of published studies with negative results more often used less discriminative tools to quantify liver fat, such as CT scan. ${ }^{129}$

The effect on liver fat of exercise-only interventions ranged from a decrease of $2 \%$ up to $50 \% .{ }^{121}$ Exercise also had a modest effect, decreasing aminotransferases levels. ${ }^{120}$

Globally, the published studies found a significant positive correlation between changes in BMI and changes in liver fat content. ${ }^{54,130}$ For each $1 \%$ decrease in body weight, studies reported $1 \%$ decrease in liver fat content. ${ }^{123}$ The effect was also more profound when baseline BMI was higher. ${ }^{120}$ However, improvements in liver steatosis were also reported in the absence of weight loss, ${ }^{56,131-133}$ suggesting that exercise exerts beneficial effects on liver steatosis that are independent of weight loss. ${ }^{54}$ This may be, in part, explained by a more consistent improvement in visceral/abdominal fat with preservation of muscle mass, ${ }^{56,127,130,132,134-137}$ in insulin resistance and lipid profile, ${ }^{135,136,138-140}$ and modification of inter-organ cross-talk with a favorable cytokine expression (for example, adiponectin and myostatin) and reduction of inflammation and oxidative stress, ${ }^{141}$ after an exercise intervention.

A predictor of the efficacy of an exercise intervention in reducing liver fat was baseline cardiorespiratory fitness, independently of total and visceral adipose tissue loss or exercise intensity. ${ }^{142}$ Cardiorespiratory fitness probably reflected the functional consequences of genetics and recent physical activity habits.

The beneficial effects of exercise on liver fat were transversal across the lifespan, with positive results from studies on adolescents ${ }^{143}$ to the elderly. ${ }^{144}$ However, the effect seemed to be more pronounced in the elderly. Exercise was also beneficial in patients with MAFLD who had normal weight at baseline. ${ }^{7}$ 
Table 2 Randomized Controlled Studies Evaluating the Effect of Aerobic Exercise on MAFLD

\begin{tabular}{|c|c|c|c|c|c|c|c|}
\hline \multirow[t]{2}{*}{ Reference } & \multirow[t]{2}{*}{ Country } & \multirow[t]{2}{*}{$\mathbf{N}$} & \multicolumn{3}{|c|}{ Intervention } & \multirow[t]{2}{*}{ Controls } & \multirow[t]{2}{*}{ Main Findings } \\
\hline & & & Intensity & $\begin{array}{l}\text { Sessions/ } \\
\text { Week }\end{array}$ & Duration & & \\
\hline $\begin{array}{l}\text { Sullivan S, } \\
2012^{|3|}\end{array}$ & USA & $\begin{array}{l}19 \text { obese } \\
\text { MAFLD } \\
\text { patients }\end{array}$ & $\begin{array}{l}45-55 \mathrm{VO}_{2} \\
\text { peak, } 30-60 \\
\text { minutes }\end{array}$ & 5 & 16 & No exercise & $\begin{array}{l}\text { - Exercise } \downarrow \text { IHLC }(10.3 \pm 4.6 \%) \\
\text { - Exercise had no effect on weight or } \\
\% \text { of body fat }\end{array}$ \\
\hline $\begin{array}{l}\text { Hallsworth } \\
K, 2015^{33}\end{array}$ & UK & $\begin{array}{l}23 \text { MAFLD } \\
\text { patients }\end{array}$ & $\begin{array}{l}\mathrm{H}-\mathrm{I} \text { interval } \\
\text { training }\end{array}$ & 3 & 12 weeks & $\begin{array}{l}\text { Standard of } \\
\text { care }\end{array}$ & $\begin{array}{l}\text { - Exercise associated with: } \\
\text { - } \downarrow \text { liver fat and whole body fat mass } \\
\text { - } \downarrow \text { ALT and AST } \\
\text { - } \uparrow \text { early diastolic filling rate } \\
\text { - No effect on glucose or lipid } \\
\text { metabolism }\end{array}$ \\
\hline $\begin{array}{l}\text { Keating SE, } \\
2015^{58}\end{array}$ & Australia & $\begin{array}{l}48 \text { inactive } \\
\text { overweight/ } \\
\text { obese adults }\end{array}$ & \multicolumn{2}{|c|}{$\begin{array}{l}\text { I. L/M-I ( } 50 \% \mathrm{VO}_{2} \text { peak), } \\
60 \mathrm{~min}, 4 x / \text { week } \\
\text { 2. } \mathrm{H}-\mathrm{I}\left(70 \% \mathrm{VO}_{2} \text { peak }\right) \text {, } \\
45 \mathrm{~min}, 3 \mathrm{x} / \text { week } \\
\text { 3. L/M-I }\left(50 \% \mathrm{VO}_{2} \text { peak), }\right. \\
45 \mathrm{~min}, 3 \times / \text { week }\end{array}$} & 8 weeks & No exercise & $\begin{array}{l}\bullet \text { L/M-I, } 60 \mathrm{~min}, 4 x / \text { week: } \downarrow \text { IHLC } 2.62 \\
\pm 1.00 \%, \downarrow \text { VAT } 386.8 \pm I 19.5 \mathrm{~cm}^{2} \\
\bullet \text { H-I, } 45 \mathrm{~min}, 3 \times / \text { week: } \downarrow \text { IHLC } 2.38 \\
\pm 0.73 \%, \downarrow \text { VAT } 258.4 \pm 87.2 \mathrm{~cm}^{2} \\
\bullet \text { L/M-I, } 45 \mathrm{~min}, 3 \times / \text { week: } \downarrow \text { IHLC } 0.84 \\
\pm 0.45 \%, \downarrow \text { VAT } 212.9 \pm 105.5 \mathrm{~cm}^{2} \\
\bullet \text { Placebo: } \uparrow \text { IHLC I. } 10 \pm 0.62 \%, \uparrow \text { VAT } \\
92.6 \pm 83.5 \mathrm{~cm}^{2}\end{array}$ \\
\hline $\begin{array}{l}\text { Zhang HS, } \\
2016^{126}\end{array}$ & China & $\begin{array}{l}220 \text { MAFLD } \\
\text { patients } \\
\text { with central } \\
\text { obesity }\end{array}$ & $\begin{array}{l}\text { I. H-I: } 65-80 \% \\
\text { maximal HR } \\
\text { 2. M-I: } 45-55 \% \\
\text { maximal HR }\end{array}$ & $\begin{array}{c}150 \\
\text { minutes }\end{array}$ & 6 months & No exercise & $\begin{array}{l}\text { - No difference on IHLC in M-I vs } \\
\text { H-I exercise, even though H-I exercise } \\
\text { associated with higher decrease in } \\
\text { body weight } \\
\text { - No effect on aminotransferases }\end{array}$ \\
\hline $\begin{array}{l}\text { Shojaee- } \\
\text { Moradie F, } \\
2016^{127}\end{array}$ & UK & $\begin{array}{l}27 \\
\text { sedentary } \\
\text { MAFLD } \\
\text { patients }\end{array}$ & $\begin{array}{l}\text { I hour at } 40- \\
60 \% \mathrm{HR} \\
\text { reserve }\end{array}$ & $4-5$ & 16 weeks & $\begin{array}{l}\text { Conventional } \\
\text { life-style } \\
\text { advice }\end{array}$ & $\begin{array}{l}\text { - Exercise versus control } \downarrow \text { IHLC, } \\
\text { visceral fat and subcutaneous } \\
\text { abdominal fat and } \uparrow \text { VLDL clearance }\end{array}$ \\
\hline $\begin{array}{l}\text { Cuthbertson } \\
\text { DS, } 2016^{140}\end{array}$ & UK & $\begin{array}{l}69 \text { MAFLD } \\
\text { patients }\end{array}$ & $\begin{array}{l}30 \% \mathrm{HR} \\
\text { reserve } 30 \\
\text { minutes } \rightarrow \\
60 \% \mathrm{HR} \\
\text { reserve } 45 \\
\text { minutes }\end{array}$ & $3 \rightarrow 5$ & 16 weeks & Counseling & $\begin{array}{l}\text { - Greater } \downarrow \text { of IHLC in intervention } \\
\text { group }(4.7 \%[0.01-9.4]) \text {, improvement } \\
\text { on insulin sensitivity and SC } \\
\text { abdominal fat }\end{array}$ \\
\hline $\begin{array}{l}\text { Rezende R, } \\
2016^{132}\end{array}$ & Brazil & $\begin{array}{l}40 \\
\text { sedentary } \\
\text { post- } \\
\text { menopausal } \\
\text { women }\end{array}$ & $\begin{array}{l}\text { Treadmill } \\
\text { aerobic } \\
\text { exercise }\end{array}$ & $\begin{array}{c}120 \\
\text { minutes }\end{array}$ & 24 weeks & No exercise & $\begin{array}{l}\text { - Exercise associated with } \downarrow \text { waist } \\
\text { circumference } \\
\text { - Exercise did not associate with } \\
\text { improvements on steatosis (by CAP- } \\
\text { Fibroscan) or glucose metabolism }\end{array}$ \\
\hline $\begin{array}{l}\text { Cheng S, } \\
2017^{139}\end{array}$ & China & $\begin{array}{l}\text { II5 patients } \\
\text { with } \\
\text { MAFLD and } \\
\text { IR, 50-65 } \\
\text { years }\end{array}$ & $\begin{array}{l}60-75 \% \mathrm{VO}_{2} \\
\text { max, } 30-60 \\
\text { minutes } \\
\pm \text { fiber- } \\
\text { enriched diet }\end{array}$ & $2-3$ & $\begin{array}{c}8.6 \\
\text { months }\end{array}$ & $\begin{array}{c}\text { No } \\
\text { intervention }\end{array}$ & $\begin{array}{l}\text { - Effect on IHLC: } \\
\text { - exercise alone: } \downarrow 224.4 \% \\
\text { - diet alone: } \downarrow 23.2 \% \\
\text { - exercise }+ \text { diet: } \downarrow 47.9 \% \\
\text { - no intervention: } \downarrow 20.9 \% \\
\text { - Only exercise associated with } \downarrow \\
\text { HbAlc }\end{array}$ \\
\hline
\end{tabular}


Table 2 (Continued).

\begin{tabular}{|c|c|c|c|c|c|c|c|}
\hline \multirow[t]{2}{*}{ Reference } & \multirow[t]{2}{*}{ Country } & \multirow[t]{2}{*}{$\mathbf{N}$} & \multicolumn{3}{|c|}{ Intervention } & \multirow[t]{2}{*}{ Controls } & \multirow[t]{2}{*}{ Main Findings } \\
\hline & & & Intensity & $\begin{array}{c}\text { Sessions/ } \\
\text { Week }\end{array}$ & Duration & & \\
\hline $\begin{array}{l}\text { Winn NC, } \\
2018^{133}\end{array}$ & USA & $\begin{array}{l}23 \text { obese } \\
\text { adults }\end{array}$ & \multicolumn{2}{|c|}{$\begin{array}{l}\mathrm{H}-\mathrm{I} \text { interval }\left(4 \mathrm{~min} 80 \% \mathrm{VO}_{2}\right. \\
\text { peak } / 3 \mathrm{~min}, 50 \% \mathrm{VO}_{2} \text { peak) } \\
\text { or } \mathrm{M}-\mathrm{I} \text { continuous ( } 55 \% \mathrm{VO}_{2} \\
\text { peak, } 60 \mathrm{~min}) \text {. Duration } \\
\text { calculated to spend } 400 \mathrm{kcal}\end{array}$} & 4 weeks & No exercise & $\begin{array}{l}\text { - Both exercises similarly } \downarrow \text { IHLC } \\
\text { (H-I }-37.0 \pm 12.4 \% \text { and M-I } 20.1 \pm 6.6 \%) \\
\text { - Exercise } \downarrow \text { postprandial insulin and } \\
\text { lipid peroxidation levels } \\
\text { - Exercise did not } \downarrow \text { BMI, visceral AT } \\
\text { or liver enzymes }\end{array}$ \\
\hline $\begin{array}{l}\text { Abdelbasset } \\
\text { WK, 2019 } 135\end{array}$ & $\begin{array}{l}\text { Saudi } \\
\text { Arabia }\end{array}$ & $\begin{array}{l}32 \text { obese } \\
\text { MAFLD } \\
\text { patients }\end{array}$ & $\begin{array}{l}\mathrm{H}-\mathrm{I} \text { interval } \\
\text { training, } 40 \\
\text { minutes }\end{array}$ & 3 & 8 weeks & No exercise & 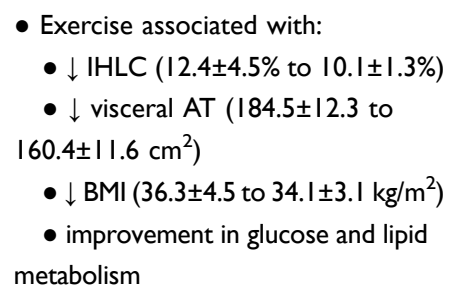 \\
\hline $\begin{array}{l}\text { Abdelbasset } \\
\text { WK, } 2020^{136}\end{array}$ & $\begin{array}{l}\text { Saudi } \\
\text { Arabia }\end{array}$ & $\begin{array}{l}72 \text { obese } \\
\text { diabetic } \\
\text { MAFLD } \\
\text { patients }\end{array}$ & $\begin{array}{l}\mathrm{H}-\mathrm{I} \text { interval vs } \\
\mathrm{M}-\mathrm{I} \text { continuous }\end{array}$ & 3 & 8 weeks & No exercise & $\begin{array}{l}\text { - No differences between } \mathrm{H}-\mathrm{I} \text { interval } \\
\text { or M-I continuous on IHLC, visceral } \\
\text { AT, BMI or glucose metabolism }\end{array}$ \\
\hline $\begin{array}{l}\text { O'Gorman P, } \\
2020^{157}\end{array}$ & Ireland & $\begin{array}{l}24 \text { biopsy- } \\
\text { proven } \\
\text { MAFLD } \\
\text { patients }\end{array}$ & $\begin{array}{l}\text { Supervised and } \\
\text { unsupervised } \\
\text { sessions }\end{array}$ & $3-5$ & 12 weeks & $\begin{array}{l}\text { Standard of } \\
\text { care }\end{array}$ & $\begin{array}{l}\text { - Exercise associated with } \downarrow \\
\text { hepatocyte ballooning and fibrosis for } \\
\text { one stage, but showed no effect on } \\
\text { steatosis, lobular inflammation or } \\
\text { NAFLD activity score }\end{array}$ \\
\hline
\end{tabular}

Abbreviations: AT, adipose tissue; BMI, body mass index; H, high; HR, heart rate; IHLC, intra-hepatic liver content; IR, insulin resistance; L, low; M, moderate, VLDL, verylow density lipoproteins.

An interesting study from China evaluated the longterm effect of 1 year of exercise intervention in 220 obese subjects with MAFLD. At the end of the experiment, exercise was associated with a decrease in visceral abdominal fat, blood pressure and intrahepatic lipid content. Interestingly, 1 year after the active intervention, the beneficial effects on blood pressure and intrahepatic lipid content persisted, albeit the effect on visceral abdominal fat was abrogated. ${ }^{126}$ This study suggests long-standing effects after an exercise intervention.

The duration/intensity of exercise necessary to improve liver steatosis is still to be determined. Globally, studies presented a dose-dependent effect between a decrease in liver fat and total training time, ${ }^{121}$ but not with the duration of each exercise session or the frequency of sessions per week. ${ }^{54}$ Liver fat content decreased $0.27 \%$ for each week of exercise intervention. $^{123}$ Importantly, interventional studies taught us that even very short interventions, as short as one week, may be beneficial, resulting in an improvement in markers of hepatocyte cell death, even though hepatic lipid content did not decrease. ${ }^{109}$

Light intensity exercise, in opposition to moderate intensity exercise, failed to elicit a decrease in liver fat. ${ }^{145}$ The lowest reported energy consumption to elicit a decrease in liver fat was $6349 \mathrm{kcal}$ during the total period of aerobic exercise, ${ }^{54}$ which is still less than the recommended for obesity management. ${ }^{146,147}$

A pivotal study evaluating the effect of exercise intensity on liver fat is the one by Keating et $\mathrm{al}^{58}$ that randomized 48 inactive and overweight/obese adults to an 8-week intervention that consisted in: 1) low to moderate intensity, high volume aerobic exercise $\left(50 \% \mathrm{VO}_{2}\right.$ peak for 60 minutes, 4 days per week); 2) high intensity, low volume aerobic exercise $\left(70 \% \mathrm{VO}_{2}\right.$ peak for 45 minutes, 3 days per week); 3) low to moderate intensity, low volume aerobic exercise $\left(50 \% \mathrm{VO}_{2}\right.$ peak for 45 minutes, 3 days per week); and 4) placebo. The authors did not find 
differences between the dose or intensity of the exercise regimen and reductions in liver fat or visceral adipose tissue.

Globally, studies comparing moderate to high-intensity exercise interventions did not find differences in the improvement of hepatic steatosis from 1 month up to 1 year, even though vigorous exercise would elicit higher weight loss in the short term. ${ }^{126,136,148}$ However, a study of 169 patients submitted to a 12-week exercise intervention did find a higher decrease in liver fat content, assessed by CAP incorporated in Fibroscan ${ }^{\circledR}$, for vigorous compared to moderate intensity exercise (32\% versus $23 \%) .{ }^{149}$

Winn et $\mathrm{al}^{133}$ randomized 23 obese subjects to a 4-week intervention with either high-intensity interval exercise training on motorized treadmill (consisting of 4 minutes of training in $80 \%$ of $\mathrm{VO}_{2}$ peak alternating with 3 minutes of active recovery at $50 \% \mathrm{VO}_{2}$ peak) or moderate intensity continuous training (at $55 \% \mathrm{VO}_{2}$ peak, for 60 minutes), versus non-exercising controls. The 2 exercise regimens were matched for energy expenditure, with 400 kcal consumed per session. Both exercise regimens achieved similar changes in liver fat and in glucose metabolism. A similar study, by Abdelbasset et al ${ }^{136}$ on 72 obese, diabetic patients with MAFLD, submitted to an 8 -week intervention, also found no differences in the effect of high-intensity interval versus moderate intensity continuous exercise on liver fat content.

Even though it might be difficult to discriminate the effect of aerobic exercise from a global lifestyle changes intervention including diet, on liver fat, some studies did specifically evaluate an exercise intervention without dietary modifications, and did find a decrease in liver fat. ${ }^{140}$ A recent meta-analysis confirmed that exercise alone without diet can induce reductions in liver fat content. ${ }^{150}$ While studies were not consensual, ${ }^{151-153}$ global evidence suggests that diet and exercise seem to have an additive effect on liver fat improvement. ${ }^{121,139,154}$ Furthermore, the combination of diet and exercise did induce synergic effects on metabolic control, either glucose and lipid metabolism or blood pressure. ${ }^{151,152}$

In rodent animal models, exercise interventions improved hepatic inflammation and fibrosis. ${ }^{92,155}$ In humans, however, there is little evidence to support it. ${ }^{147}$ A pilot study on 27 patients, with paired liver biopsies before and after a 6-month exercise intervention, did not achieve improvements in necroinflammatory activity or fibrosis. ${ }^{156}$ A 6 months interventional study with moderate intensity exercise in postmenopausal women did not find a decrease in liver fibrosis assessed by elastography. ${ }^{132}$ A recent pilot study, not controlled, on 24 patients with biopsy-proven MAFLD, performed a paired biopsy after a 12-weeks intervention with moderate to vigorous intensity aerobic exercise. In this study, half of the patients had improved 1-stage liver fibrosis and two thirds improved ballooning score, even though there was no significant improvement in steatosis or lobular inflammation. ${ }^{157}$ Also, a study on 61 sedentary obese men with NAFLD, randomized for high or moderate intensity aerobic exercise during 12 weeks, found that patients on the high-intensity arm improved liver fibrosis assessed by transient elastography. ${ }^{158}$

Human trials assessing the effect of exercise on the severity of liver disease, in patients with MAFLD, are underpowered. Also, the duration of the intervention might not have been enough. Indeed, two largepopulation epidemiological studies did show a decreased risk of having steatohepatitis and significant fibrosis in MAFLD patients who engaged vigorous (albeit not for moderate) intensity physical activity. ${ }^{42,43}$

\section{Aerobic versus Resistance Exercise and MAFLD}

The evidence for the effect of resistance exercise on MAFLD is less consistent, with studies presenting high heterogeneity. However, resistance exercise consistently improved muscle strength and function, as well as, insulin sensitivity. ${ }^{159}$

Skeletal muscle present 3 different muscle fibers: 1) type I or slow oxidative, specialized for long-duration contractile activity that resynthesizes ATP through aerobic metabolism; 2) type IIA or fast oxidative, which has moderate aerobic and anaerobic activity; and 3) IIX or fast glycolytic, which resynthesize ATP through anaerobic glycolysis. ${ }^{160}$ Aerobic training acts mainly on type I fibers and promotes an increase in aerobic capacity. Aerobic training not only modulates the muscle fibers (increasing mitochondrial biogenesis and capillary density) but it also induces cardiorespiratory adaptations in order to facilitate the body's utilization of $\mathrm{O}_{2}$. As such, it strengthens respiratory muscles and increases cardiac dimension and contractility, allowing greater filling of ventricles, resulting in an increase in stroke volume and decreased resting heart rate. $^{161}$ Aerobic exercise also improves microcirculation and arterial compliance, resulting in a favorable decrease in blood pressure. ${ }^{162}$ Conversely, anaerobic training acts mainly on type II fibers, promoting muscle hypertrophy and neural adaptation resulting in improved strength. It also increases bone density. ${ }^{163}$ 
Some studies and meta-analysis found a more profound decrease in intrahepatic lipid content (SMD $-0.28, \mathrm{p}=0.006$ ) for aerobic exercise compared to resistance exercise, ${ }^{120,164}$ while others failed to demonstrate a difference between them. ${ }^{121,122,137,165}$ Importantly, resistance exercise improved hepatic steatosis with less energy consumption, and might be better tolerated by patients with poor cardiorespiratory fitness. ${ }^{122}$ Interestingly, this anti-steatogenic energy sparing property might, in part, be explained by an increase in muscle myokines, such as irisin, which occurs during resistance but not aerobic exercise. ${ }^{166}$

Studies suggest that aerobic exercise, as compared to resistance exercise, has a more profound effect on visceral adipose tissue and glucose or lipid metabolic control. ${ }^{164,167}$ However, there is no compelling evidence that the differences in the metabolic effects of aerobic and resistance exercise are clinically significant. ${ }^{161}$ Indeed, both aerobic and resistance training can improve skeletal muscle insulin sensitivity in the muscles recruited for the exercise performance. ${ }^{87}$

Aerobic exercise requires high cardiorespiratory fitness and causes fatigue and discomfort, which has a negative impact on long-term compliance. In its turn, resistance exercise is less accessible, since it requires specialized equipment and specific exercise methods. ${ }^{122}$ In resistance exercise, it is recommended to use 7-8 different types of weight training exercises targeting major muscles, including pectoralis major, latissimus dorsi, gluteus maximus, quadriceps femoris, and hamstring muscles (eg chest press, shoulder press, vertical traction, leg press, leg extension, leg curl, abdominal crunch, and bicep curl).

Hence, both forms of exercise seem complementary. Indeed, if aerobic exercise is not tolerated, resistance exercise is an alternative, since it also can improve liver fat content. ${ }^{168,169}$

\section{Recommendations}

The American College of Sports Medicine recommends cardiorespiratory, resistance, and flexibility exercise training, beyond activities of daily living, to apparently healthy adults of all ages. ${ }^{170}$ The college recommends moderate intensity cardiorespiratory exercise training for at least 30 minutes on at least 5 days per week, for a total of at least 150 minutes per week, or vigorous intensity cardiorespiratory exercise training for at least 20 minutes on at least 3 days a week, for a total of at least 75 minutes per week. Adults are also advised to perform resistance exercise for each of the major muscle groups on 2 to 3 days per week, as well as, performing a series of flexibility exercise for each major muscle-tendon group during 60 seconds per exercise on at least 2 days per week. ${ }^{170}$ It is equally acceptable to perform one continuous session or multiple shorter sessions of at least 10 minutes. In either case, patients should gradually increase the duration, frequency, and intensity of exercise sessions.

Most guidelines on MAFLD ${ }^{171-175}$ support the recommendations from the American College of Sports Medicine for healthy adults (Table 3).

Table 3 International Guidelines on Exercise for Patients with MAFLD

\begin{tabular}{|c|c|c|c|c|c|}
\hline & AGA 2021 & AASLD 2018 & $\begin{array}{c}\text { EASL, EASD, } \\
\text { EASO } 2016\end{array}$ & NICE 2016 & WGO 2016 \\
\hline $\begin{array}{l}\text { Type of } \\
\text { exercise }\end{array}$ & Aerobic \pm resistance & Aerobic \pm resistance & $\begin{array}{l}\text { Aerobic } \pm \\
\text { resistance }\end{array}$ & Aerobic & Aerobic \\
\hline Intensity & $\begin{array}{l}\text { Moderate or } \\
\text { vigorous }\end{array}$ & Moderate & Moderate & Moderate & Moderate \\
\hline $\begin{array}{l}\text { Exercise } \\
\text { examples }\end{array}$ & & & $\begin{array}{l}\text { Brisk walking, } \\
\text { stationary cycling }\end{array}$ & $\begin{array}{l}\text { Brisk walking, } \\
\text { cycling or gardening }\end{array}$ & $\begin{array}{c}\text { Achieving heart rate } 60-75 \% \text { of } \\
\text { the age-based maximum }\end{array}$ \\
\hline $\begin{array}{l}\text { Duration and } \\
\text { frequency }\end{array}$ & $\begin{array}{c}150-300 \mathrm{~min} / \text { week } \\
\text { if moderate or } \\
75-150 \mathrm{~min} / \text { week if } \\
\text { vigorous } \\
2-3 \times / \text { week }\end{array}$ & $\begin{array}{c}150 \mathrm{~min} / \text { week or } \\
\text { increase } 60 \mathrm{~min} / \text { week }\end{array}$ & $\begin{array}{l}150 \mathrm{~min} / \text { week } \\
2-3 \mathrm{x} / \text { week }\end{array}$ & 45-60 min /day & $3-4 x /$ week \\
\hline
\end{tabular}

Abbreviations: AGA, American Gastroenterological Association; AASLD, American Association for the Study of the Liver; EASL, European Association for the Study of the Liver; EASD, European Association for the Study of Diabetes; EASO, European Association for the Study of Obesity; NICE, National Institute for Health and Care Excellence; WGO, World Gastroenterology Organization. 
One must keep in mind that patients with MAFLD often present important co-morbidities such as chronic fatigue associated with obstructive sleep apnea, cardiovascular diseases, osteoarthritis (particularly frequent in the knees) and depression with poor motivation, among others. ${ }^{3}$ Even though exercise, including vigorous exercise, seems safe in patients with those co-morbidities, including coronary disease, ${ }^{176}$ exercise prescription must be individualized for the patient's age and medical status. Importantly, even if the patient is unable to meet the minimum exercise recommended by international societies, any increase in physical activity can have beneficial effects on the hepatic and general health of the patient.

A critical issue in lifestyle modification strategies, and particularly exercise programs, is the patient's lack of motivation. ${ }^{177}$ MAFLD is still perceived by the patients as a benign condition with low impact on their health. Furthermore, even when MAFLD patients are aware of the benefits of exercise, they lack confidence and have low expectations. ${ }^{178}$ As a result, up to $75 \%$ of patients fail to achieve the recommended exercise goals. ${ }^{179}$ To increase adherence to an exercise program, instructions must be simple, goals must be attainable and measurable. ${ }^{3}$ Patients tend to adhere more to physical activity performed at home, surpassing the need to attend on-site, supervised exercise-sessions. ${ }^{180}$ Also could help, to exercise by increasing daily activities (for example, using stairs and walking) ${ }^{181}$ or by engaging in pleasant, leisure-time activities, such as dancing. ${ }^{182}$ Finally, cognitive behavioral therapy has been shown to considerably increase adherence to lifestyle interventions. ${ }^{183}$

\section{Conclusions}

MAFLD is considered the liver manifestation of a sick overwhelmed adipose tissue. Recent studies showed us that MAFLD should probably be more accurately perceived as the liver expression of sedentarism, irrespective of body weight.

Currently, we still lack an approved pharmacological treatment for MAFLD, even though MAFLD is the main chronic liver disease worldwide, and it is rapidly rising towards the top causes of end-stage liver disease in the Occidental world. However, weight loss through lifestyle changes favoring healthy diet and exercise, when accomplished, is highly effective in reverting to hepatic steatosis and even steatohepatitis and fibrosis. Exercise per se, even in the absence of diet, is also effective in decreasing liver fat content. Moreover, exercise, even when it does not elicit weight loss, is still beneficial in the management of hepatic steatosis. Evidence for the role of exercise in reverting to steatohepatitis and liver fibrosis is still scarce, but probably only occurs when engaging in long-term vigorous exercise. Nevertheless, even when exercise goals are not achieved, any increase in physical activity should be encouraged, since it has beneficial effects on the liver and in the associated metabolic disturbances.

Evidence is stronger for aerobic exercise, but probably aerobic or resistance exercise is similarly effective in the management of MAFLD.

Recommendations for exercise should be proposed to all patients with MAFLD, and hepatology clinics should implement a multidisciplinary team that would assist patients in planning an individualized exercise program according to their age and health status.

\section{Abbreviations}

ACC, acetyl CoA carboxylase; $\beta$-HAD, beta-hydroxyacylCoA-dehydrogenase; BMI, body mass index; FAS, fatty acids synthase; FGF, fibroblast growth factor; FLI, fatty liver index; IL, interleukin; MAFLD, metabolic dysfunction associated fatty liver disease; MET, metabolic equivalent task; MRS, magnetic resonance spectrometry; NAS, NAFLD fibrosis score; NHANES, National Health and Nutrition Examination Survey; PGC-1 $\alpha$, peroxisome proliferator-activated receptor gamma co-activator 1-alpha; PPAR- $\gamma$, peroxisome proliferator-activated receptor gamma; SREBP-1c, sterol regulatory-element binding protein-1c; TLR, Toll-like receptor; TNF- $\alpha$, tumor necrosis factoralpha; $\mathrm{VO}_{2}$, maximum capacity of oxygen utilization.

\section{Disclosure}

The author reports no conflicts of interest in this work.

\section{References}

1. Rodulfo JIA. Sedentary lifestyle a disease from xxi century. Clin e Investig Atheroscleros. 2019;31(5):233-240.

2. Booth FW, Roberts CK, Thyfault JP, Ruegsegger GN, Toedebusch RG. Role of inactivity in chronic diseases: evolutionary insight and pathophysiological mechanisms. Physiol Rev. 2017;97(4):1351-1402. doi:10.1152/physrev.00019.2016

3. Gerber LH, Weinstein A, Pawloski L. Role of exercise in optimizing the functional status of patients with nonalcoholic fatty liver disease. Clin Liver Dis. 2014;18(1):113-127. doi:10.1016/j.cld.20 13.09.016

4. Patterson R, McNamara E, Tainio M, et al. Sedentary behaviour and risk of all-cause, cardiovascular and cancer mortality, and incident type 2 diabetes: a systematic review and dose response meta-analysis. Eur J Epidemiol. 2018;33(9):811-829. doi:10.1007/s10654-018-0380-1 
5. Ekelund U, Steene-Johannessen J, Brown WJ, et al. Does physical activity attenuate, or even eliminate, the detrimental association of sitting time with mortality? A harmonised meta-analysis of data from more than 1 million men and women. Lancet. 2016;388 (10051):1302-1310. doi:10.1016/S0140-6736(16)30370-1

6. Ryu S, Chang Y, Jung HS, et al. Relationship of sitting time and physical activity with non-alcoholic fatty liver disease. $J$ Hepatol. 2015;63(5):1229-1237. doi:10.1016/j.jhep.2015.07.010

7. Machado MV. Nonalcoholic fatty liver disease in lean subjects: is it all metabolic-associated fatty liver disease? Hepatoma Res. 2020;6:84

8. Machado MV, Diehl AM. Pathogenesis of nonalcoholic steatohepatitis. Gastroenterology. 2016;150(8):1769-1777. doi:10. 1053/j.gastro.2016.02.066

9. Eslam M, Newsome PN, Sarin SK, et al. A new definition for metabolic dysfunction-associated fatty liver disease: an international expert consensus statement. J Hepatol. 2020;73 (1):202-209. doi:10.1016/j.jhep.2020.03.039

10. Younossi ZM. Non-alcoholic fatty liver disease - a global public health perspective. J Hepatol. 2019;70(3):531-544. doi:10.1016/j. jhep.2018.10.033

11. Goldberg D, Ditah IC, Saeian K, et al. Changes in the prevalence of hepatitis $\mathrm{C}$ virus infection, nonalcoholic steatohepatitis, and alcoholic liver disease among patients with cirrhosis or liver failure on the waitlist for liver transplantation. Gastroenterology. 2017;152(5):1090-1099. doi:10.1053/j.gastro.2017.01.003

12. Noureddin M, Vipani A, Bresee C, et al. NASH leading cause of liver transplant in women: updated analysis of indications for liver transplant and ethnic and gender variances. Am J Gastroenterol. 2018;113(11):1649-1659. doi:10.1038/s41395-018-0088-6

13. Liu Y, Zhong GC, Tan HY, Hao FB, Hu JJ. Nonalcoholic fatty liver disease and mortality from all causes, cardiovascular disease, and cancer: a meta-analysis. Sci Rep. 2019;9(1):11124. doi:10.1038/s41598-019-47687-3

14. Targher G, Byrne CD, Lonardo A, Zoppini G, Barbui C. Nonalcoholic fatty liver disease and risk of incident cardiovascular disease: a meta-analysis. $J$ Hepatol. 2016;65(3):589-600. doi:10.1016/j.jhep.2016.05.013

15. Machado MV, Cortez-Pinto H. Non-alcoholic fatty liver disease: what the clinician needs to know. World J Gastroenterol. 2014;20 (36):12956-12980. doi:10.3748/wjg.v20.i36.12956

16. Caspersen CJ, Powell KE, Christenson GM. Physical activity, exercise, and physical fitness: definitions and distinctions for health-related research. Public Health Rep. 1985;100(2):126-131.

17. Jetté M, Sidney K, Blümchen G. Metabolic equivalents (METS) in exercise testing, exercise prescription, and evaluation of functional capacity. Clin Cardiol. 1990;13(8):555-565. doi:10.1002/ clc. 4960130809

18. Caldwell S, Lazo M. Is exercise an effective treatment for NASH? Knowns and unknowns. Ann Hepatol. 2009;8(Suppl 1): S60-S66. doi:10.1016/S1665-2681(19)31828-9

19. Golabi P, Locklear CT, Austin P, et al. Effectiveness of exercise in hepatic fat mobilization in non-alcoholic fatty liver disease: systematic review. World J Gastroenterol. 2016;22(27):6318-6327. doi:10.3748/wjg.v22.i27.6318

20. Kwak MS, Kim D, Chung EG, Kim W, Kim YJ, Yoon JH. Role of physical activity in nonalcoholic fatty liver disease in terms of visceral obesity and insulin resistance. Liver Int. 2015;35 (3):944-952. doi:10.1111/liv.12552

21. Kwak MS, Kim D, Chung EG, Kim W, Kim JS. The preventive effect of sustained physical activity on incident nonalcoholic fatty liver disease. Liver Int. 2017;37(6):919-926. doi:10.1111/liv.13332

22. Byambasukh O, Zelle D, Corpeleijn E. Physical activity, fatty liver, and glucose metabolism over the life course: the lifelines cohort. Am J Gastroenterol. 2019;114(6):907-915. doi:10.14309/ ajg.0000000000000168
23. Perseghin G, Lattuada G, Cobelli F, et al. Habitual physical activity is associated with intrahepatic fat content in humans. Diabetes Care. 2007;30(3):683-688. doi:10.2337/dc06-2032

24. Zelber-Sagi S, Nitzan-Kaluski D, Goldsmith R, et al. Role of leisure-time physical activity in nonalcoholic fatty liver disease: a population-based study. Hepatology. 2008;48(6):1791-1798. doi:10.1002/hep.22525

25. Bhatt SP, Misra A, Nigam P. Nutrition and physical activity in Asian Indians with non-alcoholic fatty liver: a case control study. Diabetes Metab Syndr. 2019;13(2):1271-1274. doi:10.1016/j. dsx.2019.01.054

26. Li YF, He F, He Y, et al. Dose-response association between physical activity and non-alcoholic fatty liver disease: a case-control study in a Chinese population. BMJ Open. 2019;9 (3):e026854. doi:10.1136/bmjopen-2018-026854

27. Jang DK, Lee JS, Lee JK, Kim YH. Independent association of physical activity with nonalcoholic fatty liver disease and alanine aminotransferase levels. $J$ Clin Med. 2019;8(7):1013. doi: $10.3390 / \mathrm{jcm} 8071013$

28. Wei H, Qu H, Wang H, Deng H. Associations between sitting time and non-alcoholic fatty liver diseases in Chinese male workers: a cross-sectional study. BMJ Open. 2016;6(9):e011939. doi:10.1136/bmjopen-2016-011939

29. Croci I, Coombes JS, Sandbakk SB, et al. Non-alcoholic fatty liver disease: prevalence and all-cause mortality according to sedentary behaviour and cardiorespiratory fitness. The HUNT study. Prog Cardiovasc Dis. 2019;62(2):127-134. doi:10.1016/j. pcad.2019.01.005

30. Joo JH, Kim HJ, Park EC, Jang SI. Association between sitting time and non-alcoholic fatty liver disease in South Korean population: a cross-sectional study. Lipids Health Dis. 2020;19(1):212. doi:10.1186/s12944-020-01385-6

31. Dunstan DW, Kingwell BA, Larsen R, et al. Breaking up prolonged sitting reduces postprandial glucose and insulin responses. Diabetes Care. 2012;35(5):976-983. doi:10.2337/dc11-1931

32. Gerber L, Otgonsuren M, Mishra A, Escheik C, Stepanova M, Younossi ZM. Non-alcoholic fatty liver disease (NAFLD) is associated with low level of physical activity: a population-based study. Aliment Pharmacol Ther. 2012;36 (8):772-781. doi:10.1111/apt.12038

33. Hallsworth $\mathrm{K}$, Thoma $\mathrm{C}$, Moore S, et al. Non-alcoholic fatty liver disease is associated with higher levels of objectively measured sedentary behaviour and lower levels of physical activity than matched healthy controls. Frontline Gastroenterol. 2015;6 (1):44-51. doi:10.1136/flgastro-2014-100432

34. Keating SE, Parker HM, Pavey TG, et al. Objectively quantified physical activity and sedentary behavior in predicting visceral adiposity and liver fat. $J$ Obes. 2016;2016:2719014. doi:10.1155/2016/2719014

35. Huai P, Xun H, Reilly KH, Wang Y, Ma W, Xi B. Physical activity and risk of hypertension: a meta-analysis of prospective cohort studies. Hypertension. 2013;62(6):1021-1026. doi:10.1161/HYPERTENSIONAHA.113.01965

36. Larsson CA, Krøll L, Bennet L, Gullber B, Rastam L, Lindblad U. Leisure time and occupational physical activity in relation to obesity and insulin resistance: a population-based study from the Skaraborg Project in Sweden. Metabolism. 2012;61(4):590-598. doi:10.1016/j.metabol.2011.09.010

37. Bae JC, Suh S, Park SE, et al. Regular exercise is associated with a reduction in the risk of NAFLD and decreased liver enzymes in individuals with NAFLD independent of obesity in Korean adults. PLoS One. 2012;7(10):e46819. doi:10.1371/journal.pone.0046819

38. Miyake T, Kumagi T, Hirooka M, et al. Significance of exercise in nonalcoholic fatty liver disease in men: a community-based large cross-sectional study. $J$ Gastroenterol. 2015;50(2):230-237. doi:10.1007/s00535-014-0959-6 
39. Suzuki A, Lindor K, St Saver J, et al. Effect of changes on body weight and lifestyle in nonalcoholic fatty liver disease. J Hepatol. 2005;43(6):1060-1066. doi:10.1016/j.jhep.2005.06.008

40. Sung KC, Ryu S, Lee JY, Kim JY, Wild SH, Byrne CD. Effect of exercise on the development of new fatty liver and the resolution of existing fatty liver. $J$ Hepatol. 2016;65(4):791-797. doi:10.1016/j.jhep.2016.05.026

41. Gerage AM, Ritti-Dias RM, Balagopal PB, et al. Physical activity levels and hepatic steatosis: a longitudinal follow-up study in adults. J Gastroenterol Hepatol. 2018;33(3):741-746. doi:10.11 11/jgh.13965

42. Kistler KD, Brunt EM, Clark JM, et al. Physical activity recommendations, exercise intensity, and histological severity of nonalcoholic fatty liver disease. Am J Gastroenterol. 2011;106 (3):460-468. doi:10.1038/ajg.2010.488

43. Tsunoda K, Kai Y, Kitano N, Kuchiki T, Nagamatsu T, Nagamatsu T. Impact of physical activity on nonalcoholic steatohepatitis in people with nonalcoholic simple fatty liver: a prospective cohort study. Prev Med. 2016;88:237-240. doi:10.1016/j.ypmed.2016.04.020

44. Richter EA, Ruderman N. AMPK and the biochemistry of exercise: implications for human health and disease. Biochem J. 2009;418(2):261-275. doi:10.1042/BJ20082055

45. Church TS, Kuk JL, Ross R, Priest EL, Biltoft E, Blair SN. Association of cardiorespiratory fitness, body mass index, and waist circumference to nonalcoholic fatty liver disease. Gastroenterology. 2006;130(7):2023-2030. doi:10.1053/j.gastro.2006.03.019

46. McMillan KP, Kuk JL, Church TS, Blair SN, Ross R. Independent associations between liver fat, visceral adipose tissue, and metabolic risk factors in men. Appl Physiol Nutr Metabol. 2007;32(2):265-272. doi:10.1139/h06-112

47. Argo CK, Stine JG, Henry ZH, et al. Physical deconditioning is the common denominator in both obese and overweight subjects with nonalcoholic steatohepatitis. Aliment Pharmacol Ther. 2018;48(3):290-299. doi:10.1111/apt.14803

48. Austin P, Gerber L, Paik JM, Price JK, Escheik C, Younossi ZM. Aerobic capacity and exercise performance in nonalcoholic fatty liver disease. J Sports Med Phys Fitness. 2019;59(8):1376-1388. doi:10.23736/S0022-4707.19.09231-4

49. Canada JM, Abbate A, Collen R, et al. Relation of hepatic fibrosis in nonalcoholic fatty liver disease to left ventricular diastolic function and exercise tolerance. Am J Cardiol. 2019;123 (3):466-473. doi:10.1016/j.amjcard.2018.10.027

50. Krasnoff JB, Painter PL, Wallace JP, Bass NM, Merriman RB. Health-related fitness and physical activity in patients with nonalcoholic fatty liver disease. Hepatology. 2008;47(4):1158-1166. doi:10.1002/hep. 22137

51. Simon TG, Kim MN, Luo X, et al. Physical activity compared to adiposity and risk of liver-related mortality: results from two prospective, nationwide cohorts. $J$ Hepatol. 2020;72 (6):1062-1069. doi:10.1016/j.jhep.2019.12.022

52. Kim D, Murag S, Cholankeril G, et al. Physical activity, measured objectively, is associated with lower mortality in patients with nonalcoholic fatty liver disease. Clin Gastroenterol Hepatol. 2021;19(6):1240-1247. doi:10.1016/j.cgh.2020.07.023

53. Machado MV, Cortez-Pinto H. Diet, microbiota, obesity, and NAFLD: a dangerous quartet. Int J Med Sci. 2016;17(4):481.

54. Takahashi H, Kotani K, Tanaka K, Eguchi Y, Anzai K. Therapeutic approaches to nonalcoholic fatty liver disease: exercise intervention and related mechanisms. Front Endocrinol (Lausanne). 2018;9:588. doi:10.3389/fendo.2018.00588

55. Ismail I, Keating SE, Baker MK, Johnson NA. A systematic review and meta-analysis of the effect of aerobic vs resistance exercise training on visceral fat. Obes Rev. 2012;13(1):68-91. doi:10.1111/j.1467-789X.2011.00931.x
56. Johnson NA, Sachinwalla T, Walton DW, et al. Aerobic exercise training reduces hepatic and visceral lipids in obese individuals without weight loss. Hepatology. 2009;50(4):1105-1112. doi:10. 1002/hep.23129

57. Yu N, Ruan Y, Gao X, Sun J. Systematic review and meta-analysis of randomized, controlled trials on the effect of exercise on serum leptin and adiponectin in overweight and obese individuals. Hormone Metabol Res. 2017;49(3):164-173. doi:10.1055/s-0042-121605

58. Keating SE, Hackett DA, Parker HM, et al. Effect of aerobic exercise training dose on liver fat and visceral adiposity. J Hepatol. 2015;63(1):174-182. doi:10.1016/j.jhep.2015.02.022

59. Stanford KI, Middelbeek RJW, Townsend KL, et al. A novel role for subcutaneous adipose tissue in exercise-induced improvements in glucose homeostasis. Diabetes. 2015;64(6):2002-2014. doi: $10.2337 / \mathrm{db} 14-0704$

60. Gollisch KSC, Brandauer J, Jessen N, et al. Effects of exercise training on subcutaneous and visceral adipose tissue in normaland high-fat diet-fed rats. Am J Pysiol Endocrinol Metabol. 2009;297(2):E495-E504. doi:10.1152/ajpendo.90424.2008

61. Xu XJ, Gauthier MS, Hess DT, et al. Insulin sensitive and resistant obesity in humans: AMPK activity, oxidative stress, and depot-specific changes in gene expression in adipose tissue. J Lipid Res. 2012;53(4):792-801. doi:10.1194/jlr.P022905

62. Boden G, Duan X, Homko C, et al. Increase in endoplasmic reticulum stress-related proteins and genes in adipose tissue of obese, insulin-resistant individuals. Diabetes. 2008;57 (9):2438-2444. doi:10.2337/db08-0604

63. Le Lay S, Krief S, Farnier C, et al. Cholesterol, a cell size-dependent signal that regulates glucose metabolism and gene expression in adipocytes. J Biol Chem. 2001;276 (20):16904-16910. doi:10.1074/jbc.M010955200

64. Laurencikiene J, Skurk T, Kulyté A, et al. Regulation of lipolysis in small and large fat cells of the same subject. J Clin Endocrinol Metabol. 2011;96(12):E2045-E2049. doi:10.1210/jc.2011-1702

65. Cinti S, Mitchell G, Barbatelli G, et al. Adipocyte death defines macrophage localization and function in adipose tissue of obese mice and humans. $J$ Lipid Res. 2005;46(11):2347-2355. doi:10.1194/j1r.M500294-JLR200

66. Frohnert BI, Long EK, Hahn WS, Bernlohr DA. Glutathionylated lipid aldehydes are products of adipocyte oxidative stress and activators of macrophage inflammation. Diabetes. 2014;63 (1):89-100. doi:10.2337/db13-0777

67. Wu J, Boström P, Sparks LM, et al. Beige adipocytes are a distinct type of thermogenic fat cell in mouse and human. Cell. 2012;150(2):366-376. doi:10.1016/j.cell.2012.05.016

68. Boström P, Wu J, Jedrychowski MP, et al. A PGC1- $\alpha$-dependent myokine that drives brown-fat-like development of white fat and thermogenesis. Nature. 2012;481(7382):463-468. doi:10.1038/ nature 10777

69. Hoppeler H, Howald HC, Lindstedt SL, Claassen H, Vock P, Weibel ER. Endurance training in humans: aerobic capacity and structure of skeletal muscle. J Appl Physiol. 1985;59 (2):320-327.

70. Argilés JM, Campos N, Lopez-Pedrosa JM, Rueda R, RodriguezMañas L. Skeletal muscle regulates metabolism via interorgan crosstalk: roles in health and disease. J Am Med Dir Assoc. 2016;17(9):789-796. doi:10.1016/j.jamda.2016.04.019

71. Stanford KI, Goodyear LJ. Exercise and type 2 diabetes: molecular mechanisms regulating glucose uptake in skeletal muscle. Adv Physiol Educ. 2014;38(4):308-314

72. Rabøl R, Petersen KF, Dufour S, Flannery C, Shulman GI. Reversal of muscle insulin resistance with exercise reduces postprandial hepatic de novo lipogenesis in insulin resistant individuals. Proc Natl Acad Sci USA. 2011;108(33):13 705-13709. doi:10.1073/pnas. 1110105108 
73. Bergström J, Hermansen L, Hultman E, Saltin B. Diet, muscle glycogen and physical performance. Acta Physiol Scand. 1967;71 (2-3):140-150. doi:10.1111/j.1748-1716.1967.tb03720.x

74. Cartee GD, Farrar RP. Exercise training induces glycogen sparing during exercise by old rats. J Appl Physiol. 1988;64(1):259-265. doi:10.1152/jappl.1988.64.1.259

75. Wolfe RR, Klein S, Carraro F, Weber JM. Role of triglyceride-fatty acid cycle in controlling fat metabolism in humans during and after exercise. Am J Physiol. 1990;258(2 Pt 1):E382-E389.

76. Watt MJ, Heigenhauser GJF, Spriet LL. Intramuscular triacylglycerol utilization in human skeletal muscle during exercise: is there a controversy? J Appl Physiol. 2002;93(4):1185-1195. doi:10.11 52/japplphysiol.00197.2002

77. Johnson NA, Keating SE, George J. Exercise and the liver: implications for therapy in fatty liver disorders. Semin Liver Dis. 2012;32(1):65-79. doi:10.1055/s-0032-1306427

78. Devlin JT, Horton ES. Effects of prior high-intensity exercise on glucose metabolism in normal and insulin-resistant men. Diabetes. 1985;34(10):973-979. doi:10.2337/diab.34.10.973

79. Bhanji RA, Narayanan P, Allen AM, Malhi H, Watt KD. Sarcopenia in hiding: the risk and consequence of underestimating muscle dysfunction in nonalcoholic steatohepatitis. Hepatology. 2017;66(6):2055-2065. doi:10.1002/hep.29420

80. Huh JY. The role of exercise-induced myokines in regulating metabolism. Arch Pharm Res. 2018;41(1):14-29. doi:10.1007/ s12272-017-0994-y

81. Li F, Li Y, Duan Y, Hu CAA, Tang Y, Yin Y. Myokines and adipokines: involvement in the crosstalk between skeletal muscle and adipose tissue. Cytokine Growth Factor Rev. 2017;33:73-82. doi:10.1016/j.cytogfr.2016.10.003

82. Konopka AR, Wolff CA, Suer MK, Harber MP. Relationship between intermuscular adipose tissue infiltration and myostatin before and after aerobic exercise training. Am J Physiol Regulat Integr Comp Physiol. 2018;315(3):R461-R468. doi:10.1152/ajpregu.00030.2018

83. Deloglu W, Caligiuri A, Provenzano A, et al. Myostatin regulates the fibrogenic phenotype of hepatic stellate cells via c-jun N-terminal kinase activation. Digest Liver Dis. 2019;51 (10):1400-1408. doi:10.1016/j.dld.2019.03.002

84. Fischer CP. Interleukin-6 in acute exercise and training: what is the biological relevance? Exerc Immunol Rev. 2006;12:6-33.

85. Steensberg A, Fischer CP, Keller C, Møller K, Pedersen BK. IL-6 enhances plasma IL-1ra, IL-10, and cortisol in humans. Am J Physiol Endocrinol Metab. 2003;51(2):E433-E437. doi:10.11 52/ajpendo.00074.2003

86. Thyfault JP, Rector RS, Uptergrove GM, et al. Rats selectively bred for low aerobic capacity have reduced hepatic mitochondrial oxidative capacity and susceptibility to hepatic steatosis and injury. J Physiol. 2009;587(8):1805-1916. doi:10.1113/jphysiol. 2009.169060

87. Fuente FP, Quezada L, Sepúlveda C, et al. Exercise regulates lipid droplet dynamics in normal and fatty liver. Biochim Et Biophys Acta Mol Cell Biol Lipids. 2019;1864(12):158519. doi:10.1016/j. bbalip.2019.158519

88. Rector RS, Thyfault JP, Morris RT, et al. Daily exercise increases hepatic fatty acid oxidation and prevents steatosis in Otsuka Long-Evans Tokushima Fatty rats. Am J Physiol Gastroenterol Liver Physiol. 2008;294(3):G619-G626. doi:10.1152/ajpgi.004 28.2007

89. Petridou A, Tsalouhidou S, Tsalis G, Schulz T, Michna H, Mougios V. Long-term exercise increases the DNA binding activity of peroxisome proliferator-activated receptor gamma in rat adipose tissue. Metabolism. 2007;56(8):1029-1036. doi:10.1016/ j.metabol.2007.03.011
90. Rector RS, Thyfault JP, Laye MJ, et al. Cessation of daily exercise dramatically alters precursors of hepatic steatosis in Otsuka Long-Evans Tokushima Fatty (OLETF) rats. J Physiol. 2008;586 (17):4241-4249. doi:10.1113/jphysiol.2008.156745

91. Rector RS, Uptergrove GM, Morris EM, et al. Daily exercise vs. caloric restriction for prevention of nonalcoholic fatty liver disease in the OLETF rat model. Am J Physiol Gastroenterol Liver Physiol. 2011;300(5):G874-G883. doi:10.1152/ajpgi.00510.2010

92. Linden MA, Sheldon RD, Meers GM, et al. Aerobic exercise training in the treatment of non-alcoholic fatty liver disease related fibrosis. J Physiol. 2016;594(18):5271-5284. doi:10.1113/JP272235

93. Gomez-Cabrera MC, Domenech E, Viña J. Moderate exercise is an antioxidant: upregulation of antioxidant genes by training. Free Radic Biol Med. 2008;44(2):126-131. doi:10.1016/j. freeradbiomed.2007.02.001

94. Tung BT, Rodriguez-Bies E, Thanh HN, et al. Organ and tissue-dependent effect of resveratrol and exercise on antioxidant defenses of old mice. Aging Clin Experimen Res. 2015;27 (6):775-783. doi:10.1007/s40520-015-0366-8

95. Lima FD, Stamm DN, Della-Pace ID, et al. Swimming training induces liver mitochondrial adaptations to oxidative stress in rats submitted to repeated exhaustive swimming bouts. PLoS One. 2013;8(2):e55668. doi:10.1371/journal.pone.0055668

96. Lima TI, Monteiro IC, Valença S, et al. Effect of exercise training on liver antioxidant enzymes in STZ-diabetic rats. Life Sci. 2015;128:64-71. doi:10.1016/j.1fs.2015.01.031

97. Avula CPR, Fernandes G. Modulation of antioxidant enzymes and lipid peroxidation in salivary gland and other tissues in mice by moderate treadmill exercise. Aging. 1999;11(4):246-252.

98. Venditti P, Di Meo S. Effect of training on antioxidant capacity, tissue damage, and endurance of adult male rats. Int $J$ Sports Med. 1997;18(7):497-502. doi:10.1055/s-2007-972671

99. Gleeson M, Bishop NC, Stensel DJ, Lindley MR, Mastana SS, Nimmo MA. The anti-inflammatory effects of exercise: mechanisms and implications for the prevention and treatment of disease. Nat Rev Immunol. 2011;11(9):607-615. doi:10.1038/nri3041

100. Kawanishi N, Yano H, Mizokami T, Takahashi M, Oyanagi E, Suzuki K. Exercise training attenuates hepatic inflammation, fibrosis and macrophage infiltration during diet induced-obesity in mice. Brain Behav Immun. 2012;26(6):931-941. doi:10.1016/j.bbi.2012.04.006

101. El-Kader SMA, Al-Jiffri O, Al-Shreef FM. Markers of liver function and inflammatory cytokines modulation by aerobic versus resisted exercise training for nonalcoholic steatohepatitis patients. African Health Sci. 2014;14(3):551-557. doi:10.4314/ahs.v14i3.8

102. Gleeson M, McFarlin B, Flynn M. Exercise and toll-like receptors. Exerc Immunol Rev. 2006;12:34-53.

103. Wang J, Song H, Tang X, et al. Effect of exercise training intensity on murine T-regulatory cells and vaccination response. Scand J Med Sci Sports. 2012;22(5):643-652. doi:10.1111/j.16000838.2010.01288.x

104. Guo R, Liong EC, So KF, Fung ML, Tipoe GL. Beneficial mechanisms of aerobic exercise on hepatic lipid metabolism in non-alcoholic fatty liver disease. Hepatobil Pancreat Dis Int. 2015;14(2):139-144. doi:10.1016/S1499-3872(15)60355-1

105. Boveris A, Navarro A. Systemic and mitochondrial adaptive responses to moderate exercise in rodents. Free Radic Biol Med. 2008;44(2):224-229. doi:10.1016/j.freeradbiomed.2007.08.015

106. Gonçalves IO, Oliveira PJ, Ascensão A, Magalhães J. Exercise as a therapeutic tool to prevent mitochondrial degeneration in nonalcoholic steatohepatitis. Eur J Clin Invest. 2013;43(11):1184-1194.

107. Gonçalves IO, Passos E, Rocha-Rodrigues S, et al. Physical exercise prevents and mitigates non-alcoholic steatohepatitis-induced liver mitochondrial structural and bioenergetics impairments. Mitochondrion. 2014;15:40-51. doi:10.1016/j.mito.2014.03.012 
108. Gonçalves IO, Passos E, Diogo CV, et al. Exercise mitigates mitochondrial permeability transition pore and quality control mechanisms alterations in nonalcoholic steatohepatitis. Appl Physiol Nutr Metabol. 2016;41(3):298-306. doi:10.1139/apnm2015-0470

109. Fealy CE, Haus JM, Solomon TPJ, et al. Short-term exercise reduces markers of hepatocyte apoptosis in nonalcoholic fatty liver disease. J Appl Physiol. 2012;113(1):1-6. doi:10.1152/ japplphysiol.00127.2012

110. Hajighasem A, Farzanegi P, Mazaheri Z. Effects of combined therapy with resveratrol, continuous and interval exercises on apoptosis, oxidative stress, and inflammatory biomarkers in the liver of old rats with non-alcoholic fatty liver disease. Arch Physiol Biochem. 2019;125(2):142-149. doi:10.1080/ 13813455.2018.1441872

111. Piguet AC, Saran U, Simillion C, et al. Regular exercise decreases liver tumors development in hepatocyte-specific PTEN-deficient mice independently of steatosis. J Hepatol. 2015;62(6):1296-1303. doi:10.1016/j.jhep.2015.01.017

112. Guarino M, Kumar P, Felser A, et al. Exercise attenuates the transition from fatty liver to steatohepatitis and reduces tumor formation in mice. Cancers. 2020;12(6):1407. doi:10.3390/ cancers 12061407

113. Arfianti A, Pok S, Barn V, et al. Exercise retards hepatocarcinogenesis in obese mice independently of weight control. J Hepatol. 2020;73(1):140-148. doi:10.1016/j.jhep.2020.02.006

114. Kern T, Blond MB, Hansen TH, et al. Structured exercise alters the gut microbiota in humans with overweight and obesity-A randomized controlled trial. Int J Obes. 2020;44 (1):125-135. doi:10.1038/s41366-019-0440-y

115. Hughes A, Dahmus J, Rivas G, et al. Exercise training reverses gut dysbiosis in patients with biopsy-proven nonalcoholic steatohepatitis: a proof of concept study. Clin Gastroenterol Hepatol. 2020;S1542(20):31222-31224.

116. Huber Y, Pfirrmann D, Gebhardt I, et al. Improvement of non-invasive markers of NAFLD from an individualised, web-based exercise program. Aliment Pharmacol Ther. 2019;50 (8):930-939. doi:10.1111/apt.15427

117. Motiani KK, Collado MC, Eskelinen JJ, et al. Exercise training modulates gut microbiota profile and improves endotoxemia. Med Sci Sports Exerc. 2020;52(1):94-104. doi:10.1249/MSS.000 0000000002112

118. Carbajo-Pescador S, Porras D, Garciá-Mediavilla MV, et al. Beneficial effects of exercise on gut microbiota functionality and barrier integrity, and gut-liver crosstalk in an in vivo model of early obesity and non-alcoholic fatty liver disease. Dis Models Mechan. 2019;12(5):dmm039206. doi:10.1242/dmm.039206

119. Keating SE, Hackett DA, George J, Johnson NA. Exercise and non-alcoholic fatty liver disease: a systematic review and meta-analysis. J Hepatol. 2012;57(1):157-166. doi:10.1016/j. jhep.2012.02.023

120. Orci LA, Gariani K, Oldani G, Delaune V, Morel P, Toso C. Exercise-based interventions for non-alcoholic fatty liver disease: a meta- analysis and meta-regression. Clin Gastroenterol Hepatol. 2016;14(10):1398-1411. doi:10.1016/j.cgh.2016.04.036

121. Kenneally S, Sier JH, Moore JB. Efficacy of dietary and physical activity intervention in non-alcoholic fatty liver disease: a systematic review. BMJ Open Gastroenterol. 2017;4(1): e000139-e000151. doi:10.1136/bmjgast-2017-000139

122. Hashida R, Kawaguchi T, Bekki M, et al. Aerobic vs. resistance exercise in non-alcoholic fatty liver disease: a systematic review. J Hepatol. 2017;66(1):142-152. doi:10.1016/j.jhep.2016.08.023

123. Sargeant JA, Gray LJ, Bodicoat DH, et al. The effect of exercise training on intrahepatic triglyceride and hepatic insulin sensitivity: a systematic review and meta-analysis. Obes Rev. 2018;19 (10):1446-1459. doi:10.1111/obr.12719
124. Smart NA, King N, McFarlane JR, Graham PL, Dieberg G. Effect of exercise training on liver function in adults who are overweight or exhibit fatty liver disease: a systematic review and meta-analysis. Br J Sports Med. 2018;52(13):834-843. doi:10. 1136/bjsports-2016-096197

125. Wang ST, Zheng J, Peng HW, et al. Physical activity intervention for non-diabetic patients with non-alcoholic fatty liver disease: a meta-analysis of randomized controlled trials. BMC Gastroenterol. 2020;20(1):66-77. doi:10.1186/s12876-020-01204-3

126. Zhang HJ, Pan LL, Ma ZM, et al. Long-term effect of exercise on improving fatty liver and cardiovascular risk factors in obese adults: a 1-year follow-up study. Diabetes Obes Metab. 2017;19 (2):284-289. doi:10.1111/dom.12809

127. Shojaee-Moradie F, Cuthbertson DJ, Barrett M, et al. Exercise training reduces liver fat and increases rates of VLDL clearance but not VLDL production in NAFLD. J Clin Endocrinol Metabol. 2016;101(11):4219-4228. doi:10.1210/jc.2016-2353

128. Whyte MB, Shojaee-Moradie F, Sharaf SE, et al. HDL-apoA-I kinetics in response to $16 \mathrm{wk}$ of exercise training in men with nonalcoholic fatty liver disease. Am J Physiol Endocrinol Metab. 2020;318(6):E839-E847. doi:10.1152/ajpendo.00019.2020

129. Devries MC, Samjoo IA, Hamadeh MJ, Tarnopolsky MA. Effect of endurance exercise on hepatic lipid content, enzymes, and adiposity in men and women. Obesity. 2008;16(10):2281-2288. doi:10.1038/oby.2008.358

130. Brouwers B, Schrauwen-Hinderling VB, Jelenik T, et al. Exercise training reduces intrahepatic lipid content in people with and people without nonalcoholic fatty liver. Am J Physiol Endocrinol Metab. 2018;314(2):E165-E173. doi:10.1152/ajpendo.00266.2017

131. Sullivan S, Kirk EP, Mittendorfer B, Patterson BW, Klein S. Randomized trial of exercise effect on intrahepatic triglyceride content and lipid kinetics in nonalcoholic fatty liver disease. Hepatology. 2012;55(6):1738-1745. doi:10.1002/hep. 25548

132. Rezende REF, Duarte SMB, Stefano JT, et al. Randomized clinical trial: benefits of aerobic physical activity for 24 weeks in postmenopausal women with nonalcoholic fatty liver disease. Menopause. 2016;23(8):876-883. doi:10.1097/GME.0000000000000647

133. Winn NC, Ying L, Rector RS, Parks EJ, Ibdah JA, Kanaley JA. Energy-matched moderate and high intensity exercise training improves nonalcoholic fatty liver disease risk independent of changes in body mass or abdominal adiposity - a randomized trial. Metabolism. 2018;78:128-140. doi:10.1016/j.metabol.2017.08.012

134. Dekker MJ, Lee SJ, Hudson R, et al. An exercise intervention without weight loss decreases circulating interleukin-6 in lean and obese men with and without type 2 diabetes mellitus. Metabolism. 2007;56(3):332-338. doi:10.1016/j.metabol.2006.10.015

135. Abdelbasset WK, Tantawy SA, Kamel DM, Alqahtani BA, Soliman GS. A randomized controlled trial on the effectiveness of 8-week high-intensity interval exercise on intrahepatic triglycerides, visceral lipids, and health-related quality of life in diabetic obese patients with nonalcoholic fatty liver disease. Medicine. 2019;98 (12):e14918. doi:10.1097/MD.0000000000014918

136. Abdelbasset WK, Tantawy SA, Kamel DM, et al. Effects of high-intensity interval and moderate- intensity continuous aerobic exercise on diabetic obese patients with nonalcoholic fatty liver disease: a comparative randomized controlled trial. Medicine. 2020;99(10):e19471. doi:10.1097/MD.0000000000019471

137. Bacchi E, Negri C, Targher G, et al. Both resistance training and aerobic training reduce hepatic fat content in type 2 diabetic subjects with nonalcoholic fatty liver disease (the RAED2 randomized trial). Hepatology. 2013;58(4):1287-1295. doi:10.1002/ hep. 26393

138. Cassidy S, Thoma C, Worthsworth K, et al. High intensity intermittent exercise improves cardiac structure and function and reduces liver fat in patients with type 2 diabetes: a randomised controlled trial. Diabetologia. 2016;59(1):56-66. doi:10.1007/s00125-015-3741-2 
139. Cheng S, Ge J, Zhao C, et al. Effect of aerobic exercise and diet on liver fat in pre-diabetic patients with non-alcoholic-fatty-liverdisease: a randomized controlled trial. Sci Rep. 2017;7(1):15952. doi:10.1038/s41598-017-16159-x

140. Cuthbertson DJ, Shojaee-Moradie F, Sprung VS, et al. Dissociation between exercise-induced reduction in liver fat and changes in hepatic and peripheral glucose homoeostasis in obese patients with non-alcoholic fatty liver disease. Clin Sci. 2016;130 (2):93-104. doi:10.1042/CS20150447

141. Oh KW, Tsujimoto T, Kim B, et al. Weight-loss-independent benefits of exercise on liver steatosis and stiffness in Japanese men with NAFLD. JHEP Rep. 2021;3(3):100253. doi:10.1016/j. jhepr.2021.100253

142. Kantartzis K, Thamer C, Peter A, et al. High cardiorespiratory fitness is an independent predictor of the reduction in liver fat during a lifestyle intervention in non-alcoholic fatty liver disease. Gut. 2009;58(9):1281-1288. doi:10.1136/gut.2008.151977

143. van der Heijden GJ, Wang ZJ, Chu ZD, et al. A 12-week aerobic exercise program reduces hepatic fat accumulation and insulin resistance in obese, Hispanic adolescents. Obesity. 2010;18 (2):384-390. doi:10.1038/oby.2009.274

144. Finucane FM, Sharp SJ, Purslow LR, et al. The effects of aerobic exercise on metabolic risk, insulin sensitivity and intrahepatic lipid in healthy older people from the Hertfordshire Cohort Study: a randomised controlled trial. Diabetologia. 2010;53 (4):624-631. doi:10.1007/s00125-009-1641-z

145. Nath P, Panigrahi MK, Sahu MK, et al. Effect of exercise on NAFLD and its risk factors: comparison of moderate versus low intensity exercise. J Clin Transl Hepatol. 2020;8(2):120-126. doi:10.14218/JCTH.2019.00012

146. St George A, Bauman A, Johnston A, Farrell G, Chey T, George J. Independent effects of physical activity in patients with nonalcoholic fatty liver disease. Hepatology. 2009;50 (1):68-76. doi:10.1002/hep.22940

147. Keating SE, George J, Johnson NA. The benefits of exercise for patients with non-alcoholic fatty liver disease. Expert Rev Gastroenterol Hepatol. 2015;9(10):1247-1250. doi:10.1586/ 17474124.2015.1075392

148. Zhang HJ, He J, Pan LL, et al. Effects of moderate and vigorous exercise on nonalcoholic fatty liver disease: a randomized clinical trial. JAMA Intern Med. 2016;176(8):1074-1082. doi:10.1001/ jamainternmed.2016.3202

149. Oh S, Shida T, Yamagishi K, et al. Moderate to vigorous physical activity volume is an important factor for managing nonalcoholic fatty liver disease: a retrospective study. Hepatology. 2015;61 (4):1205-1215. doi:10.1002/hep.27544

150. Baker CJ, Martinez-Huenchullan FS, D’Souza M, et al. Effect of exercise on hepatic steatosis: are benefits seen without dietary intervention? A systematic review and meta-analysis. J Diabetes. 2021;13(1):63-77. doi:10.1111/1753-0407.13086

151. Tamura Y, Tanaka Y, Sato F, et al. Effects of diet and exercise on muscle and liver intracellular lipid contents and insulin sensitivity in type 2 diabetic patients. J Clin Endocrinol Metabol. 2005;90 (6):3191-3196. doi:10.1210/jc.2004-1959

152. Shah K, Stufflebam A, Hilton TN, Sinacore DR, Klein S, Villareal DT. Diet and exercise interventions reduce intrahepatic fat content and improve insulin sensitivity in obese older adults. Obesity. 2009;17(12):2162-2168. doi:10.1038/oby.2009.126

153. Larson-Meyer DE, Newcomer BR, Heilbronn LK, et al. Effect of 6-month calorie restriction and exercise on serum and liver lipids and markers of liver function. Obesity. 2008;16(6):1155-1362. doi:10.1038/oby.2008.201

154. Goodpaster BH, Delany JP, Otto AD, et al. Effects of diet and physical activity interventions on weight loss and cardiometabolic risk factors in severely obese adults: a randomized trial. JAMA. 2010;304(16):1795-1802. doi:10.1001/jama.2010.1505
155. Linden MA, Fletcher JA, Morris EM, et al. Treating NAFLD in OLETF rats with vigorous-intensity interval exercise training. Med Sci Sports Exerc. 2015;47(3):556-567. doi:10.1249/ MSS.0000000000000430

156. Hickman IJ, Byrne NM, Croci I, et al. A pilot randomised study of the metabolic and histological effects of exercise in non-alcoholic steatohepatitis. $J$ Diabetes Metab. 2013;4 (8): 1000300 .

157. O'Gorman P, Naimimohasses S, Monaghan A, et al. Improvement in histological endpoints of MAFLD following a 12-week aerobic exercise intervention. Aliment Pharmacol Ther. 2020;52 (8):1387-1398.

158. Oh S, So R, Shida $\mathrm{T}$, et al. High-intensity aerobic exercise improves both hepatic fat content and stiffness in sedentary obese men with nonalcoholic fatty liver disease. Sci Rep. 2017;7:43029-43041. doi:10.1038/srep43029

159. Keating SE, Adams LA. Exercise in NAFLD: just do it. J Hepatol. 2016;65(4):671-673. doi:10.1016/j.jhep.2016.06.022

160. Wilson JM, Loenneke JP, Jo E, Wilson GJ, Zourdos MC, Kim JS. The effects of endurance, strength, and power training on muscle fiber type shifting. J Strength Condition Res Publish. 2012;26 (6):1724-1729. doi:10.1519/JSC.0b013e318234eb6f

161. Yang Z, Scott CA, Mao C, Tang J, Farmer AJ. Resistance exercise versus aerobic exercise for type 2 diabetes: a systematic review and meta-analysis. Sports Med. 2014;44(4):487-499. doi:10.1007/s40279-013-0128-8

162. Cardoso CG, Gomides RS, Queiroz ACC, et al. Acute and chronic effects of aerobic and resistance exercise on ambulatory blood pressure. Clinics. 2010;65(3):317-325. doi:10.1590/S180759322010000300013

163. Hughes DC, Ellefsen S, Baar K. Adaptations to endurance and strength training. Cold Spring Harb Perspect Med. 2018;8(6): a029769. doi:10.1101/cshperspect.a029769

164. Slentz CA, Bateman LA, Willis LH, et al. Effects of aerobic vs. resistance training on visceral and liver fat stores, liver enzymes, and insulin resistance by HOMA in overweight adults from STRRIDE AT/RT. Am J Physiol Endocrinol Metab. 2011;301 (5):E1033-E1039. doi:10.1152/ajpendo.00291.2011

165. Shamsoddini A, Sobhani V, Chehreh MEG, Alavian SM, Zaree A. Effect of aerobic and resistance exercise training on liver enzymes and hepatic fat in Iranian men with nonalcoholic fatty liver disease. Hepat Mon. 2015;15(10):e31434. doi:10.5812/ hepatmon.31434

166. Kim HJ, Lee HJ, So B, Son JS, Yoon D, Song W. Effect of aerobic training and resistance training on circulating irisin level and their association with change of body composition in overweight/obese adults: a pilot study. Physiolog Res. 2016;65 (2):271-279. doi:10.33549/physiolres.932997

167. Ghamarchehreh ME, Shamsoddini A, Alavian SM. Investigating the impact of eight weeks of aerobic and resistance training on blood lipid profile in elderly with non-alcoholic fatty liver disease: a randomized clinical trial. Gastroenterol Hepatol Bed Bench. 2019;12(3):190-196.

168. Hallsworth K, Fattakhova G, Hollingsworth KG, et al. Resistance exercise reduces liver fat and its mediators in non-alcoholic fatty liver disease independent of weight loss. Gut. 2011;60 (9):1278-1283. doi:10.1136/gut.2011.242073

169. Zelber-Sagi S, Buch A, Yeshua H, et al. Effect of resistance training on non-alcoholic fatty-liver disease a randomized-clinical trial. World $J$ Gastroenterol. 2014;20 (15):4382-4392. doi:10.3748/wjg.v20.i15.4382

170. Garber CE, Blissmer B, Deschenes MR, et al. Quantity and quality of exercise for developing and maintaining cardiorespiratory, musculoskeletal, and neuromotor fitness in apparently healthy adults: guidance for prescribing exercise. Med Sci Sports Exerc. 2011;43(7):1334-1359. 
171. Younossi ZM, Corey KE, Lim JK. AGA clinical practice update on lifestyle modification using diet and exercise to achieve weight loss in the management of nonalcoholic fatty liver disease: expert review. Gastroenterology. 2021;160(3):912-918. doi:10.1053/j. gastro.2020.11.051

172. Chalasani N, Younossi ZM, Lavine JE, et al. The diagnosis and management of nonalcoholic fatty liver disease: practice guidance from the American association for the study of liver diseases. Hepatology. 2018;67(1):328-357.

173. Marchesini G, Day CP, Dufour JF, et al. EASL-EASD-EASO clinical practice guidelines for the management of non-alcoholic fatty liver disease. J Hepatol. 2016;64(6):1388-1402.

174. Glen J, Floros L, Day CP, Pryke R. Non-alcoholic fatty liver disease (NAFLD): summary of NICE guidance. BMJ. 2016;354 i4428. doi:10.1136/bmj.i4428

175. LaBrecque DR, Abbas Z, Anania F, et al. World Gastroenterology Organisation global guidelines: nonalcoholic fatty liver disease and nonalcoholic steatohepatitis. J Clin Gastroenterol. 2014;48 (6):467-473. doi:10.1097/MCG.0000000000000116

176. Rognmo Ø, Moholdt T, Bakken H, et al. Cardiovascular risk of high- versus moderate-intensity aerobic exercise in coronary heart disease patients. Circulation. 2012;126(12):1436-1440. doi:10.1161/CIRCULATIONAHA.112.123117

177. Marchesini G, Petta S, Dalle Grave R. Diet, weight loss, and liver health in nonalcoholic fatty liver disease: pathophysiology, evidence, and practice. Hepatology. 2016;63(6):2032-2043. doi:10.1002/hep. 28392
178. Frith J, Day CP, Robinson LE, Elliott C, Jones DEJ, Newton JL. Potential strategies to improve uptake of exercise interventions in non-alcoholic fatty liver disease. J Hepatol. 2010;52(1):112-116. doi:10.1016/j.jhep.2009.10.010

179. Stine JG, Soriano C, Schreibman I, et al. Breaking down barriers to physical activity in patients with nonalcoholic fatty liver disease. Dig Dis Sci. 2020;1-8. doi:10.1007/s10620-020-06673-w

180. Aoike DT, Baria F, Kamimura MA, Ammirati A, Cuppari L. Home-based versus center-based aerobic exercise on cardiopulmonary performance, physical function, quality of life and quality of sleep of overweight patients with chronic kidney disease. Clin Exp Nephrol. 2018;22(1):87-98. doi:10.1007/s10157-017-1429-2

181. Andersen RE, Wadden TA, Bartlett SJ, Zemel B, Verde TJ, Franckowiak SC. Effects of lifestyle activity vs structured aerobic exercise in obese women: a randomized trial. JAMA. 1999;281 (4):335-340. doi:10.1001/jama.281.4.335

182. Mangeri F, Montesi L, Forlani G, Dalle Grave R, Marchesini G. A standard ballroom and Latin dance program to improve fitness and adherence to physical activity in individuals with type 2 diabetes and in obesity. Diabetol Metabol Syndr. 2014;6:74. doi:10.1186/1758-5996-6-74

183. Moscatiello S, Di Luzio R, Bugianesi E, et al. Cognitivebehavioral treatment of nonalcoholic fatty liver disease: a propensity score-adjusted observational study. Obesity. 2011;19(4):763-770. doi:10.1038/oby.2010.254

\section{Publish your work in this journal}

Diabetes, Metabolic Syndrome and Obesity: Targets and Therapy is an international, peer-reviewed open-access journal committed to the rapid publication of the latest laboratory and clinical findings in the fields of diabetes, metabolic syndrome and obesity research. Original research, review, case reports, hypothesis formation, expert opinion and commentaries are all considered for publication. The manuscript management system is completely online and includes a very quick and fair peer-review system, which is all easy to use. Visit http://www.dovepress.com/testimonials.php to read real quotes from published authors. 